\title{
Geophysical and Hydrogeological Groundwater Prospectivity Mapping in the Kraaipan Granite-Greenstone Terrain, Southeast Botswana
}

\author{
Rubeni T. Ranganai1 ${ }^{*}$, Moikwathai D. Moidaki' ${ }^{1}$ James G. King1, Zibisani B. Bagai2 \\ ${ }^{1}$ Department of Physics, University of Botswana, Gaborone, Botswana \\ ${ }^{2}$ Department of Geology, University of Botswana, Gaborone, Botswana \\ Email: *ranganai@mopipi.ub.bw
}

How to cite this paper: Ranganai, R.T., Moidaki, M.D., King, J.G. and Bagai, Z.B. (2017) Geophysical and Hydrogeological Groundwater Prospectivity Mapping in the Kraaipan Granite-Greenstone Terrain, Southeast Botswana. Journal of Water Resource and Protection, 9, 1270-1298.

https://doi.org/10.4236/jwarp.2017.911082

Received: July 5, 2017

Accepted: October 28, 2017

Published: October 31, 2017

Copyright $\odot 2017$ by authors and Scientific Research Publishing Inc. This work is licensed under the Creative Commons Attribution International License (CC BY 4.0).

http://creativecommons.org/licenses/by/4.0/

(c) $\underset{\mathrm{EY}}{\mathrm{C}}$ Open Access

\begin{abstract}
Application of regional geophysical methods for hydrogeological purposes has increased over the last two decades especially in arid and semi-arid areas. A project to map the Kraaipan granite-greenstone terrain in southeast Botswana has recently been undertaken using regional aeromagnetic and gravity data with the aim to map the rocks at depth to understand the geology while the secondary objective was to subsequently assess the mineralization and groundwater potential in the area. An integrated analysis of the aeromagnetic and gravity data and their derived/processed products is hereby investigated for groundwater for drinking and agricultural purposes. The studies include: subsurface characterisation and delineation of structural framework suitable for groundwater exploration and determination of petrophysical relationships used to link the geophysical properties (e.g., density) to hydrological properties (e.g., porosity). The results of interpretation indicate that the rocks are under $\sim 50 \mathrm{~m}$ of Kalahari cover and the study area is composed of three aquifers: the extensive hard rock aquifer (granitic and volcanic), the important (fractured) karst aquifer and the minor sedimentary aquifer. The area is dissected by an ENE-to-EW-trending dyke swarm visible on the regional aeromagnetic data and much clearer on high resolution aeromagnetic data. Minor fault and/or dyke elements of NW-SE and NE-SW trend are observed. Spectral analysis reveals three main average ensample interfaces at depths of 0.7 $\mathrm{km}, 1.99 \mathrm{~km}$ and $4.8 \mathrm{~km}$. The linear Euler solutions maps reveal that the majority depths to top of magnetic bodies range from $40 \mathrm{~m}$ to $400 \mathrm{~m}$ throughout the survey area. The shallowest depths are the most significant one in this case as they probably relate to depth of bedrock and thickness of regolith or thickest sediments. For 2695 existing boreholes analysed, maximum borehole depth is $482 \mathrm{~m}$ (mean $108 \mathrm{~m}$ ), and almost half (1263) were dry with another 972 hav-
\end{abstract}


ing low yield $\left(1-5 \mathrm{~m}^{3} / \mathrm{hr}\right)$ and 432 yielding $6-49 \mathrm{~m}^{3} / \mathrm{hr}$ and only 28 above 50 $\mathrm{m}^{3} / \mathrm{hr}$ (maximum $\sim 160 \mathrm{~m}^{3} / \mathrm{hr}$ ) and an average water strike of $64 \mathrm{~m}$. There is very little correlation between interpreted hydrogeological features and the existing borehole locations. The study shows the importance of preliminary geophysical investigations before ground borehole siting and drilling in order to improve borehole success rates and/or reduce costs inherent in groundwater projects.

\section{Keywords}

Aeromagnetic Data, Gravity Data, Crystalline Basement, Karst Aquifer, Groundwater Prospectivity, Borehole Yield, Southeast Botswana

\section{Introduction}

A project to map the Archaean Kraaipan greenstone belt (KGB) under approximately $50 \mathrm{~m}$ of Kalahari cover in southeast Botswana has recently been undertaken [1] using regional aeromagnetic and gravity data. The primary objectives were to map the rocks at depth to understand the 3D geology while the secondary objective was to subsequently promote mineral and groundwater exploration in the area. Groundwater represents the largest stock of accessible freshwater and accounts for about one-third of freshwater withdrawals globally ([2] and references therein). There are increased demands for groundwater resources in the southern Africa region due to population increases and socio-economic development, for drinking, mining activities and associated settlements, small-scale irrigation, rural agro-industries, and agricultural and livestock purposes [3]. Botswana is semi-arid and rainfall is unreliable such that surface water and groundwater recharge are limited. Therefore, to ensure that a secure amount of groundwater is available, systematic development and management planning should be established. Application of geophysical methods for hydrogeological purposes has become imperative especially in such arid and semi-arid areas in order to increase the probability of successful drilling of water wells. The principal reason for the growing interest in using geophysical methods for hydrogeological studies is that geophysics provides spatially distributed models of physical properties in regions that are difficult to sample using conventional hydrological methods [2]. The geophysical models often reveal more detail compared with models derived from hydrogeological data, such as pump tests and observations of hydraulic heads. Furthermore, geophysical methods are less invasive and comparatively inexpensive ([4] and references therein). It is also possible to integrate GIS, remote sensing, and geophysical surveys to derive thematic layers of surface parameters such as resistivity, susceptibility, aquifer thickness/extent, and/or fault maps [5] [6] [7] [8] [9]. Further, some researchers have used the geophysical data to determine important hydraulic properties [4] [10].

In this study, an integrated analysis of aeromagnetic and gravity data and their 
derived/processed products over a regional scale is investigated for groundwater for drinking and agricultural (mainly livestock) purposes in the Kraaipan granite-greenstone terrain in southeast Botswana. In hard rock areas it is not sufficient to consider only the weathered layer; deep saturated fractures in bedrock are also potential targets of groundwater exploration while dykes are known to be barriers to groundwater flow or preferential pathways [7] [9] [11]. In addition, paleochannels and/or paleovalleys hidden in the subsurface also support an inherited preferential groundwater flow and recharge [9] [12] [13]. The basis for the present hydrogeophysical survey is understanding the geological setting of the area, nature of stratigraphy and tectonism so as to have a better understanding of the prevailing hydrogeological conditions; thus delineating a buried framework suitable for groundwater flow and storage [7] [9] [14]. Processing of the gravity and aeromagnetic data sets by 3D Euler deconvolution, shaded relief, derivatives and analytic signal techniques further map/locate the important structures. Thus the studies include: subsurface characterisation, delineation of structural frameworks suitable for groundwater exploration and analysis of existing boreholes. Determination of petrophysical relationships used to link the geophysical properties to hydrological properties is also considered [4] [6] [10]. Eventually, the studies seek to quantify subsurface architecture that influence flow (such as hydrostratigraphy and preferential pathways); and estimate hydrological properties (such as porosity) and state variables (such as saturation) ([15] [16] and references therein).

\section{Regional Geology and Hydrogeology Ease of Use}

The Kraaipan granite-greenstone terrain constitutes the western central part of the Archaean Kaapvaal craton in SE Botswana and comprises greenstones, felsic gneiss, migmatite and unfoliated granite [1] [17] [18] [19] [20]. The Late Archaean Transvaal/Weterberg Supergroups as well as volcanic rocks of the Ventersdorp Supergroup and Tertiary sedimentary rocks of the Kalahari Group cover a significant portion of the area. Important regional geological units in the study area $\left(24.3^{\circ} \mathrm{E}\right.$ to $25.8^{\circ} \mathrm{E}$ and $25^{\circ} \mathrm{S}$ to $25.8^{\circ} \mathrm{S}$; Figure 1 and Figure 2), which constitute the Ngwaketse and Southeast administrative districts, include the Kraaipan-Madibe greenstone belt, the Mmathethe granite, the Kanye and Lobatse Volcanic Formations, the younger Karoo sediments as well as Tertiary-Recent Kalahari sediments [1] [17] [19]. The greenstones consist of three narrow NNW-striking belts (Stella, Kraaipan, Madibe; Figure 1) dominated by mafic metavolcanic rocks interlayered with ferruginous and siliceous metasedimentary rocks, mainly BIF and ferruginous chert [19] [21]. The surrounding granitoid rocks include tonalitic and trondhjemitic gneisses (TTG), granodiorites and adamellites [17]. The terrain is intruded by the Neoarchaean Gaborone Igneous Complex that includes A-type granitoids, anorthosites, rhyolites and subsidiary mafic rocks, represented by the Mmathethe granite [19] [22]. The generalized lithostratigraphy in the area is summarised in Table 1. 

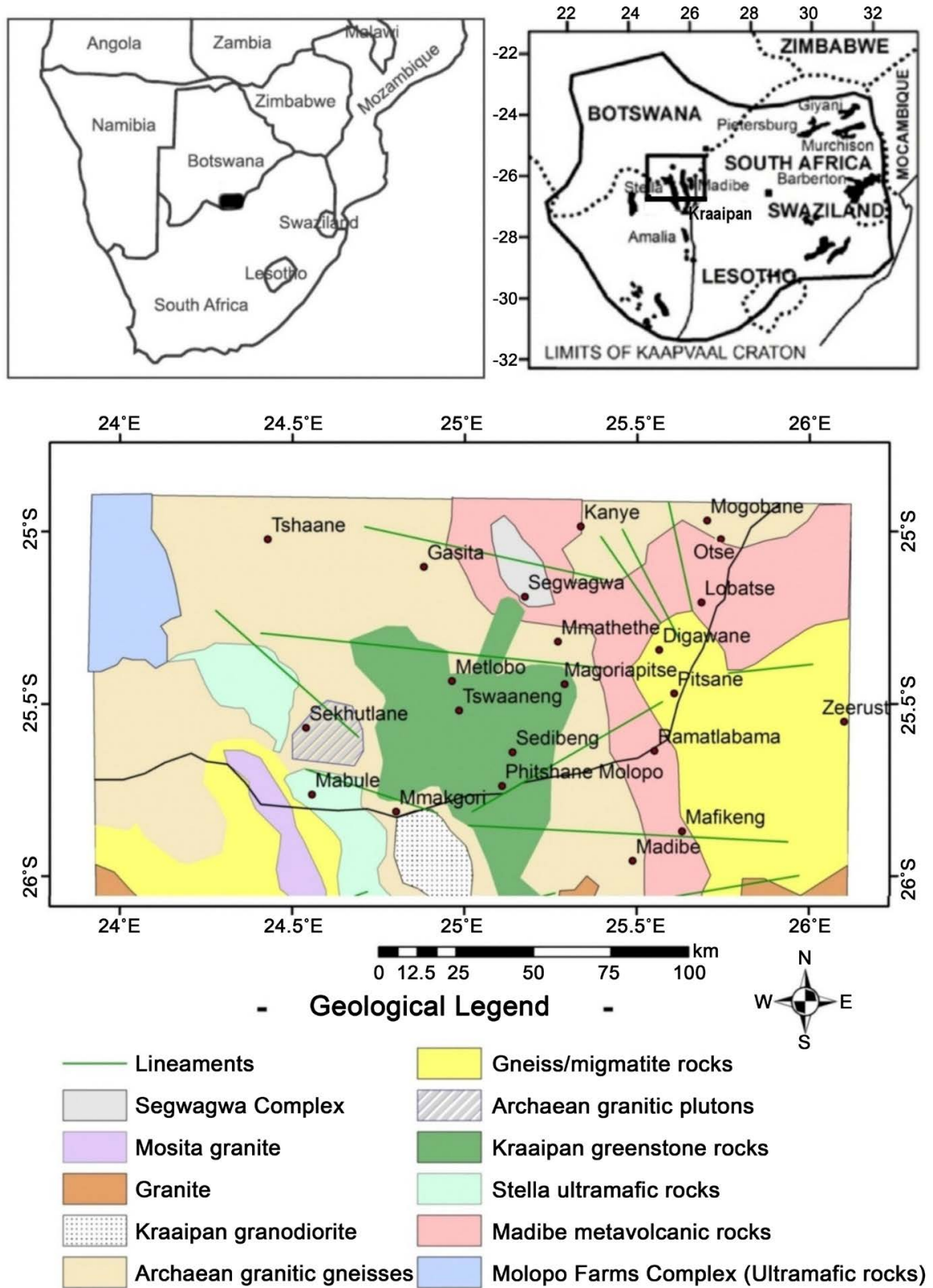

Figure 1. Simplified geology of Kraaipan granite-greenstone terrain in SE Botswana and NW South Africa based on geological mapping and geophysical interpretation [1].

Table 1. Summary lithostratigraphic table of the study area.

\begin{tabular}{ccc}
\hline Rock type & Age (Ma) & Source/reference \\
Segwagwa-Masoke Igneous Complex 999 & $2054 \pm 9$ & {$[26]$} \\
Late-Stage Granites & $2665 \pm 1.8$ & {$[27]$} \\
Kanye Volcanic Formation & $2783.8 \pm 1.1$ & {$[19]$} \\
Mmathethe Granite & $2775.2 \pm 7.4$ & {$[19]$} \\
Mosita Adamelite & $2749 \pm 3$ to $2791 \pm 8$ & {$[17][28]$} \\
Kraaipan Granodiorite & $2846 \pm 22$ to $2915 \pm 15$ & {$[17][28]$} \\
Basement Gneisses & $2816 \pm 16$ to $3070 \pm 7$ & {$[17][28]$} \\
Kraaipan Group BIF & $3410 \pm 61 / 64$ & {$[17]$} \\
\hline
\end{tabular}


There is a general paucity of geological outcrop in the region due to cover by the Kalahari sediments, and critically, the configuration and structure of rock units at depth was unknown until recently when geophysical interpretation was undertaken [1]. Some minor banded iron formation (BIF) outcrops have been mapped in the Molopo River in the border area in the south with the main N-S trending outcrop constituting the $\sim 20 \mathrm{~km}$ long Mosi ridge to the north [23]. Kalahari sediments cover the region and ranges from 0 to $100 \mathrm{~m}$ thick as indicated by borehole data and geophysical modelling [1]. The major fractures and lineaments have an ENE and WNW orientation, with secondary features trending N-S and S-W. The latter, which are often of tensional origin, may play an important part in groundwater circulation [24]. Structural features associated with faulting are important targets for groundwater exploration, as it occurs along vertical and horizontal (bedding planes) structures in these rocks [25].

The Botswana National Master Plan Study [29] [30] recognises 4 aquifer types based on the type of water transmissive voids:

1) Fractured $\rightarrow$ Ghanzi Group, patches of Waterberg, Transvaal, Ventersdorp, and Archaean rocks;

2) Fractured porous $\rightarrow$ most common (e.g. Ntane Sandstone, Ecca \& Dwyka groups);

3) Porous $\rightarrow$ Kalahari sands and alluvium (perched aquifers);

4) Karstified fractured $\rightarrow$ least common (dolomite and limestone) (SE Botswana).

The central part largely comprises of igneous and metamorphic rocks $\rightarrow$ Basement granites/gneisses including amphibolites, quartzites and schists, with some calcrete deposits.

The extreme eastern part is under Transvaal and Waterberg Supergroups with minor/some igneous and metamorphic rocks $\rightarrow$ Dolomite formation: dolomite and subordinate chert, shale and quartzite; quartzite, shale, sandstone and conglomerate. Ventersdop Supergroup $\rightarrow$ Lobatse/Kanye volcanics: tuff, felsite, greywacke, felsic porphyry and agglomerate.

Within the study area, the western part is mainly under Kalahari beds and Karoo Supergroup rocks with minor Waterberg Supergroup $\rightarrow$ sand, clay, calcrete and pan sediments (up to $100 \mathrm{~m}$ thick); mudstone, sandstone, carbonaceous shale; quartzite, shale, sandstone and conglomerate.

With regards groundwater potential in the study area (Figure 2), the granite complex and the volcanics in general show poor aquifer characteristics (low primary porosity) because of a lack of well-connected open fracture systems although fair yields are reported from boreholes in volcanics west of Lobatse. The gneisses in general form slightly better water-bearing layers with several fair-yielding boreholes in the Barolong farms area [24]. Aquifers with a fair yield are frequently encountered in fracture zones of the arenitic sediments of the Transvaal and Waterberg Supergroups but productivity decreases westwards where these rocks dip below thick Kalahari beds, obviously because of a reduction of recharge [24]. The best groundwater resources occur in the Transvaal dolomites and the Karoo sandstones, 

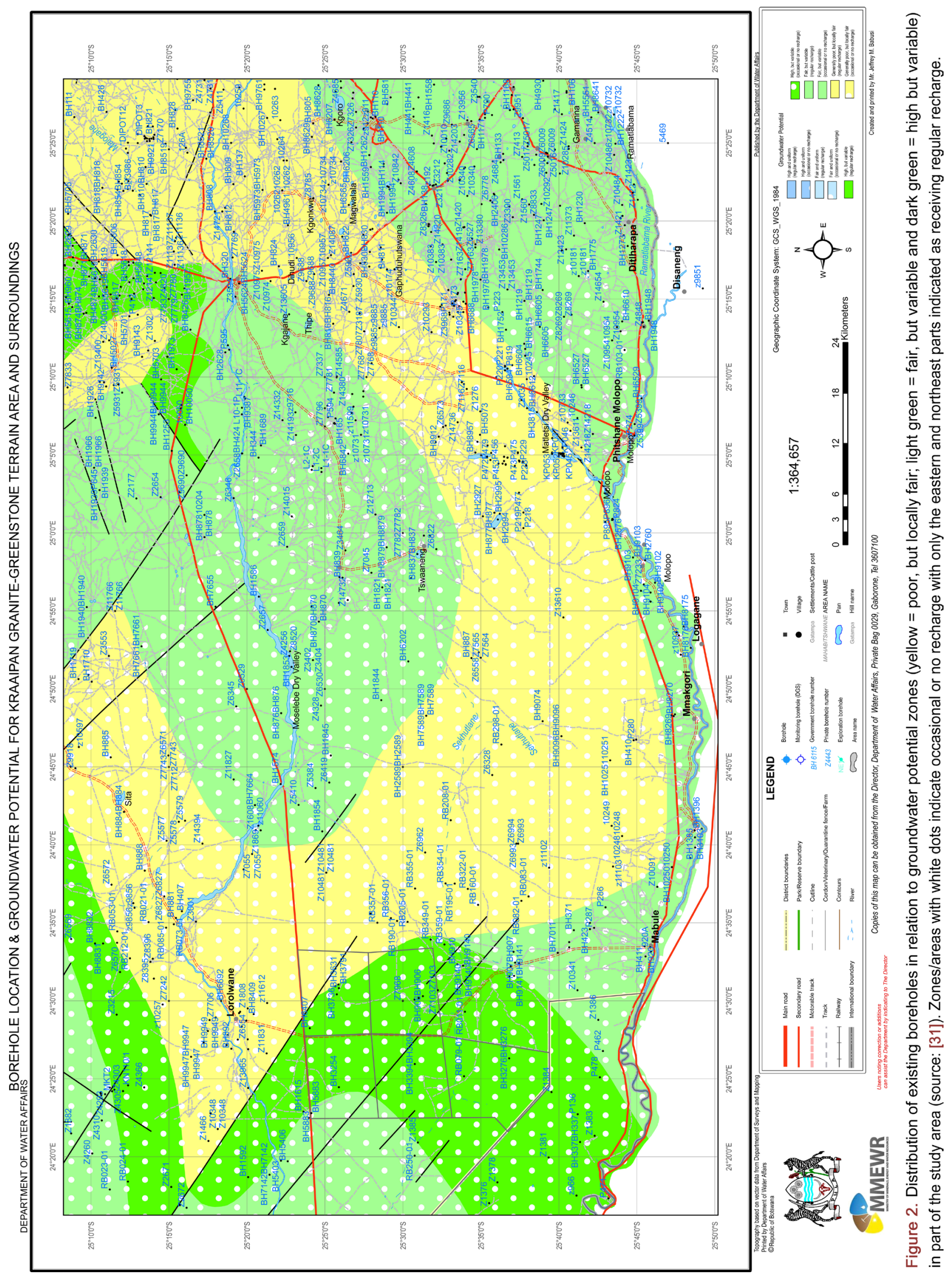
with runoff from the slopes in quatzites and shales contributing to the replenishment of these aquifers.

Groundwater flow direction is generally to the SW and recharge is significant from the Molopo River which forms the border with South Africa, particularly during floods.

Almost 3000 boreholes have been drilled by government $(\mathrm{BH})$ and private individuals $(Z)$ within the study area $\left(\leq 22,000 \mathrm{~km}^{2}\right)$ to date [31] (Figure 2). The large number of boreholes attests to the need for groundwater for domestic use and livestock in the area, and the government's commitment to provision of such social facilities. Clustering of boreholes appears to follow groundwater potential zones (Figure 2) and/or existing aquifers/wellfields (e.g., Ramotswa aquifer/wellfield). Borehole clusters also partly follow settlements along main roads and/or railway line, close to communities.

There were a few data base problems noted, mainly data not consistently reliable; thus borehole screening included discarding/rejecting those with water strike depth and/or yield but with zero total drill depth (89), with the remainder sorted by yield. A few others have doubtful location, plotting in South Africa. For 2695 existing boreholes retained and analysed, maximum borehole depth is 482 (mean 108), and almost half (1263) were dry with another 972 having low yield (1 - 5 $\mathrm{m}^{3} / \mathrm{hr}$ ) and 432 yielding $6-49 \mathrm{~m}^{3} / \mathrm{hr}$ and only 28 above $50 \mathrm{~m}^{3} / \mathrm{hr}$ (maximum $\sim 160 \mathrm{~m}^{3} / \mathrm{hr}$ ) (Figure 3). Average water strike depth is $64 \mathrm{~m}$ and the maximum is $310 \mathrm{~m}$ (maximum drill depth of $482 \mathrm{~m}$ ). There is multiple water strike for some boreholes (710), suggesting presence of confined aquifers.

BHs with WStrk $\geq 1 \mathrm{~m} \rightarrow 1719$

BHs with Yield $\geq 1 \mathrm{~m}^{3} / \mathrm{hr} \rightarrow 1432$

BHs with Yield $\geq 6 \mathrm{~m}^{3} / \mathrm{hr} \rightarrow 460$

References [7] [11] [32] note poor understanding of the hydrogeological

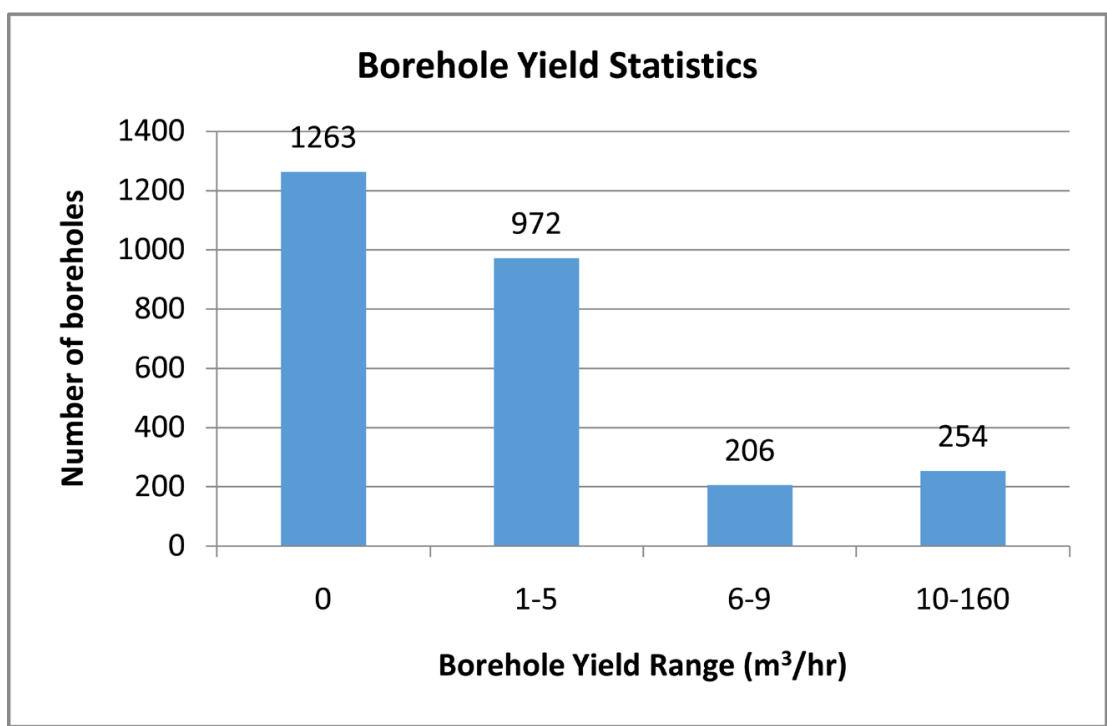

Figure 3. Borehole yield $\left(\mathrm{m}^{3} / \mathrm{hr}\right)$ statistics subdivided into the three main groups of poor, moderate and high or very good. Note the large number of dry boreholes. 
structure and poor siting (rather than groundwater potential) as the main cause of well failure in many developing countries, particularly in Precambrian basement aquifers. In the study area, the older surrounding gneisses and younger geological formations like the Kanye and Lobatse volcanics and sandstones (Ventersdop Supergroup) constitute important groundwater aquifers [24] [29] [33], and can be investigated using the available potential field data [7] [9] [14] [34].

\section{Geophysical Data and Hydrogeological Problems/Investigations}

Gravity and aeromagnetic data are routinely used for geological exploration to get information about subsurface geology under vegetation and regolith cover [35] [36]. These types of methods can be used to identify rock units and major structures by applying filter enhancements, image processing and interpretation methods [36] [37]. In addition, these products are useful for identifying target areas for mineral and groundwater exploration [7] [9] [14] [34] [38] [39].

Groundwater in crystalline/metamorphic areas is mainly controlled by two factors: tectonic fracturing (intensity \& intersections) and weathering development (deep/thick desirable [7] [9] [11]) while in karst environments it is the developed solution channels and voids that are critical [29]. A karst aquifer may be present even when there are no discernable karst landforms at the surface and gravity data are suitable for identifying/mapping them and the characteristic channels/cavities/voids. On the other hand, the thickness of sediments or the depth to basement is important for sedimentary aquifers, with both gravity and magnetic data yielding this information. In general, different hydrogeological problems to be solved that could benefit from geophysics include (e.g., Table 2):

1) The aquifer geometry (location of its bottom, top, and outlet) in alluvial and/or sedimentary deposits and in stratified volcanic layers;

2) Characteristics of fractured rocks (location of faults and/or fissures, characteristics of groundwater flow and circulation);

3) Knowledge of the hydraulic properties of the aquifer (porosity, clay content, transmissivity, permeability of the porous medium);

4) Quality of the water (fresh, salty, heavily mineralized, contaminated);

5) Monitoring of water flow (recharge) and interpretation pertaining to future effects of exploitation (discharge);

6) Geohazards as a result of withdrawal (e.g., in karst areas).

Faults are usually interpreted from aeromagnetic (AM) data as:

1) Sharp gradients, boundaries or contacts between areas of different magnetic relief, level (magnitude) or texture $\rightarrow$ morphology [7] [9] [40].

2) Disruptions and/or deflections of magnetic zones/features/trends $\rightarrow$ displacement (wrench faults/shears) with lateral movements [7] [9] [40].

3) Linear magnetic lows (magnetite destruction due to pedogenesis and oxidation $\rightarrow$ maghemite, hematite or limonite which are weak in spontaneous magne- 
tization at an ambient temperature [9] [41]).

4) Narrow, linear magnetic highs $\rightarrow$ either dykes or magnetite enrichment from metamorphism.

5) Weathering $\rightarrow$ areas of less quartz-rich rocks/facies [7] [9].

The alluvial-illuvial pedogenic process also causes a substantial loss of magnetic minerals for the top soil and the sediments. Thus, the parent crystalline basement remains magnetically stronger than the top soil or sediments in general, and provides an ideal situation for the magnetic method to map basement buried below the soil/sediment cover [9] [41] [42].

A pseudo-lithology can also be derived from aeromagnetic data by characterizing magnetic facies of a rock using its percent magnetite and its spatial distribution [7] [9] $\rightarrow$ apparent susceptibility map [7].

The hydrogeological applications of the potential field data within the study area are summarized in Table 2.

\section{Geophysical Data Processing Techniques}

A number of commonly applied potential field transformations and image processing techniques were applied to both data sets to enhance both shallow, short wavelength features for lithological contact and structural mapping as well as medium wavelengths for the purpose of regional crustal structure. These include shaded relief imaging, vertical and horizontal derivatives, analytic signal, apparent density/susceptibility mapping, upward continuation, automatic gain control, directional cosine filter, 3D Euler deconvolution and spectral analysis [36] [37] [43] [44]. Each technique helps to display the edges of source bodies and lateral contrasts in physical property, which are mainly caused by lithological and structural changes in the buried basement. Only those techniques with

Table 2. Hydrogeological applications of gravity/magnetic data and products.

\begin{tabular}{|c|c|c|}
\hline \multirow[b]{2}{*}{ Aquifer Type/Characteristics } & \multicolumn{2}{|c|}{ Airborne/Ground Geophysical Methods } \\
\hline & Magnetics (AM)/Gradiometry & Gravity/Gradiometry (AGG) \\
\hline $\begin{array}{l}\text { Porous/sedimentary (Kalahari sands } \\
\text { and alluvium, sandstone, siltstone, } \\
\text { high transmissivity and permeability } \\
\text { K) }\end{array}$ & $\begin{array}{l}\text { Non-magnetic; depth to basement, thickness } \\
\text { of sediments, mapping aquifer boundaries, } \\
\text { palaeo-channels, preferential fluid flow paths; } \\
\text { groundwater barriers; depth of weathered zone }\end{array}$ & $\begin{array}{l}\text { Low density; basement depth/ sediments/aquifer } \\
\text { thickness, mapping aquifer boundaries, } \\
\text { recharge/ discharge/storage, palaeo-channels, } \\
\text { depth of the weathered zone; stratigraphy; } \\
\text { lithological contrasts; porosity }\end{array}$ \\
\hline $\begin{array}{l}\text { Fractured porous (more storativity } \\
\text { than in porous; Ntane sandstone, } \\
\text { Ecca/Dwyka groups) }\end{array}$ & $\begin{array}{l}\text { Mapping fractures and intruding dykes (barriers } \\
\text { to groundwater) }\end{array}$ & $\begin{array}{l}\text { Mapping horst and grabben structures; } \\
\text { aquifer boundaries }\end{array}$ \\
\hline $\begin{array}{l}\text { Fractured (hard rocks: igneous and } \\
\text { metamorphic; crystalline basement; } \\
\text { weathered zones, faults/shear zones, } \\
\text { dykes) }\end{array}$ & $\begin{array}{l}\text { Mapping weathered zones, faults/fractures \& } \\
\text { shear zones (magnetic lows) and dykes (highs } \\
\text { or lows) }\end{array}$ & $\begin{array}{l}\text { Mapping of faults/shear zones \& dykes (depending } \\
\text { on their width), weathered zone }\end{array}$ \\
\hline $\begin{array}{l}\text { Karstified (fractured dolomites and } \\
\text { limestone, weathered; surrounded by } \\
\text { shale and chert) }\end{array}$ & $\begin{array}{l}\text { Magnetic lows, mapping aquifer boundaries, } \\
\text { fractures }\end{array}$ & $\begin{array}{l}\text { Gravity lows, mapping aquifer boundaries, } \\
\text { voids/cavities and fractures/channels. }\end{array}$ \\
\hline
\end{tabular}


maps/figures presented or discussed are briefly described below.

The original aeromagnetic data were subjected to a Reduction to the Pole (RTP) and International Geomagnetic Reference (IGRF) correction. The RTP transformation usually involves an assumption that, the total magnetizations of most rocks align parallel or anti-parallel to the earth's main field (declination $=12.58^{\circ}$, inclination $=62.72^{\circ}$ and IGRF total intensity value $=29,000 \mathrm{nT}$ for the study area). This results in anomalies lying directly over the causative bodies [37] leading to easier and improved interpretation. The IGRF correction removes the earth's main geomagnetic field for the particular year of survey, resulting in magnetic responses mainly due to geological features.

The initial improvement of structural elements from the aeromagnetic data was achieved by shaded relief and colour-shadow maps that rely on artificial illumination of the data mimicking topography [43] [45]. The combination of the images allows accentuation of linear features perpendicular to the light source while information on the anomaly magnitude or intensity is retained in the colour component [42] [44]. They also effectively display both short wavelength and medium wavelength anomalies as well as curvilinear and elliptical features (e.g., plutons and/or mafic sills) [44].

Derivatives of the potential field data are probably the most important functions for both qualitative and quantitative geological interpretation. Various combinations of vertical and horizontal derivatives were used to further remove or suppress the regional trends in the data, and assist in qualitative edge detection of the linear geological structures (dykes, faults and shear zones) [37] [38] [42] [44]. The analytic signal amplitude (ASA) of potential field data is the magnitude of the squares of the derivatives, and for magnetic data it has the added advantage of independence of the magnetization direction of the source [36] [37] [46] [47]. The ASA is symmetrical and peaks directly over the edges of wide bodies and the centres of narrow bodies thus providing obvious indications of dense or magnetic source geometry [42]. The most useful and popular quantitative technique that uses derivatives is $3 \mathrm{D}$ Euler deconvolution [48] which calculates the spatial position and depth of the gravity/magnetic body, thus fully locating the source. Standard 3D Euler deconvolution is used for relatively rapid delineation of linear features (structural mapping) and contacts between the sedimentary rocks and basement rocks, and rapid depth estimation. However, the quality and/or accuracy of the results, particularly the depth estimates, depends on adequate sampling of the data, proper choice of structural index and window size [49] [50].

Fourier spectral analysis (or wavelength filtering) in recent years has also become a widely utilized tool for the processing and interpretation of potential field data. Energy spectral analysis provides a technique for quantitative studies of large and complex aeromagnetic or gravity data sets. The logarithm of the radial average of the energy spectrum (the square of the Fourier amplitude spectrum) is plotted versus the radial frequency. The slope of each segment provides 
the depth to the top of an ensemble of magnetic or gravity bodies. A typical energy spectrum for magnetic data may exhibit three parts; a deep source component, a shallow source component and a noise component. For wavenumbers in cycles $/ \mathrm{km}$, the depth to a statistical ensemble of sources is determined from the expression: slope $=-4 \pi \mathrm{h}[51]$.

The following list summarizes the important geophysical processes applied, geological structures mapped, and corresponding hydrogeological significance.

Pseudoshading and derivatives $\rightarrow$ structural mapping (faults, dykes, BIFs) $\rightarrow$ either groundwater conduits/pathways or barriers.

Susceptibility; Euler deconvolution; spectral analysis $\rightarrow$ saprolite/regolith mapping (weathered zone thickness; depth to bedrock) $\rightarrow$ approximate thickness of potential aquifer.

Euler deconvolution; spectral analysis $\rightarrow$ sediment thickness, depth to bedrock $\rightarrow$ maximum thickness of potential aquifer.

\section{Geophysical Data}

\subsection{Aeromagnetic Data and Geostructural Correlation}

Botswana and South Africa are both completely covered by regional aeromagnetic data ( $1 \mathrm{~km}$ line spacing, $150 \mathrm{~m}$ mean terrain clearance, $\sim 70 \mathrm{~m}$ sample spacing); with higher resolution aeromagnetic data for selected areas (line spacing $150 \mathrm{~m}$, flight altitude $70 \mathrm{~m}, \sim 20 \mathrm{~m}$ sample spacing). Merged data are presented in Figure 4 and Figure 5 below as colour-shadow maps, with merging processes covered in detail in [1].

To correlate magnetic anomalies with rock units, it is noteworthy that sedimentary rocks are generally non-magnetic, whereas igneous rocks rich in iron and magnesium (mafic to ultramafic) tend to be very magnetic [9] [36] [41]. Granite intrusions and hornfels contact aureoles can also be magnetic [52]. In this paper all aeromagnetic results are displayed as digital image maps; they are reduction to the pole map, colour-shaded total intensity map and vertical derivative map. Many more images were generated during this study, but are not presented for clarity (i.e., to reduce redundancy). The general interpretation is also aided by higher resolution on-screen images.

The map in Figure 4 has the RTP applied and International Geomagnetic Reference Field (IGRF) already applied and thus reflects residual magnetic intensity level ranges from around $-330.0 \mathrm{nT}$ to over $280.0 \mathrm{nT}$ with the shapes of the anomalies approximately centered over their respective causative bodies. The map shows rather complex crustal magnetization pattern with different locations of high and low magnetic intensities. It exhibits some different types of positive (magenta and red colours) and negative (light and dark blue colours) anomalies. Accordingly, the western and the northern parts of the map area are occupied by two major positive magnetic belts. This map elucidates two major positive magnetic belts trending E-W in the north and NW-SE occupied in the northwestern part (Mabule to Lerolwane). The Segwagwa Complex is represented by a large 
roughly oval (NNW-trending) highly magnetic feature with average width of about $10 \mathrm{~km}$. Another feature of probably similar composition is seen around Gasita, though with irregular shape (Figure 4). The map also reveals prominent wide negative zones in elongated and irregular shapes distributed at the central parts of the mapped area. The major negative anomaly occurs at the central part (see Mmakgori, Metlobo and Mokgoriapitse villages). Based on the results of enhanced maps, it is quite likely that magnetic quiet areas are widely distributed in the central part of the study area and usually exhibit very low magnetic relief. These areas (Mmakgori to Metlobo) correspond to areas covered by a blanket of Tertiary-Recent Kalahari sediments [19]. These areas are faulted and folded as recognized both in the field and the geophysical maps. The magnetically moderate areas, such as those in the Papatlo-Ramatlabama and Metlojane villages have accentuated magnetic relief with lineaments and anomalies having amplitudes of up to $200 \mathrm{nT}$. Most of the magnetic anomalies in these areas are observed over plutonic rock exposures.

Structurally, the colour-shading accentuates several linear and curvilinear features that could be dykes, faults and/or intrusions clearly observed, even without any major wavelength filtering of the data. The Kraaipan greenstone belt contains

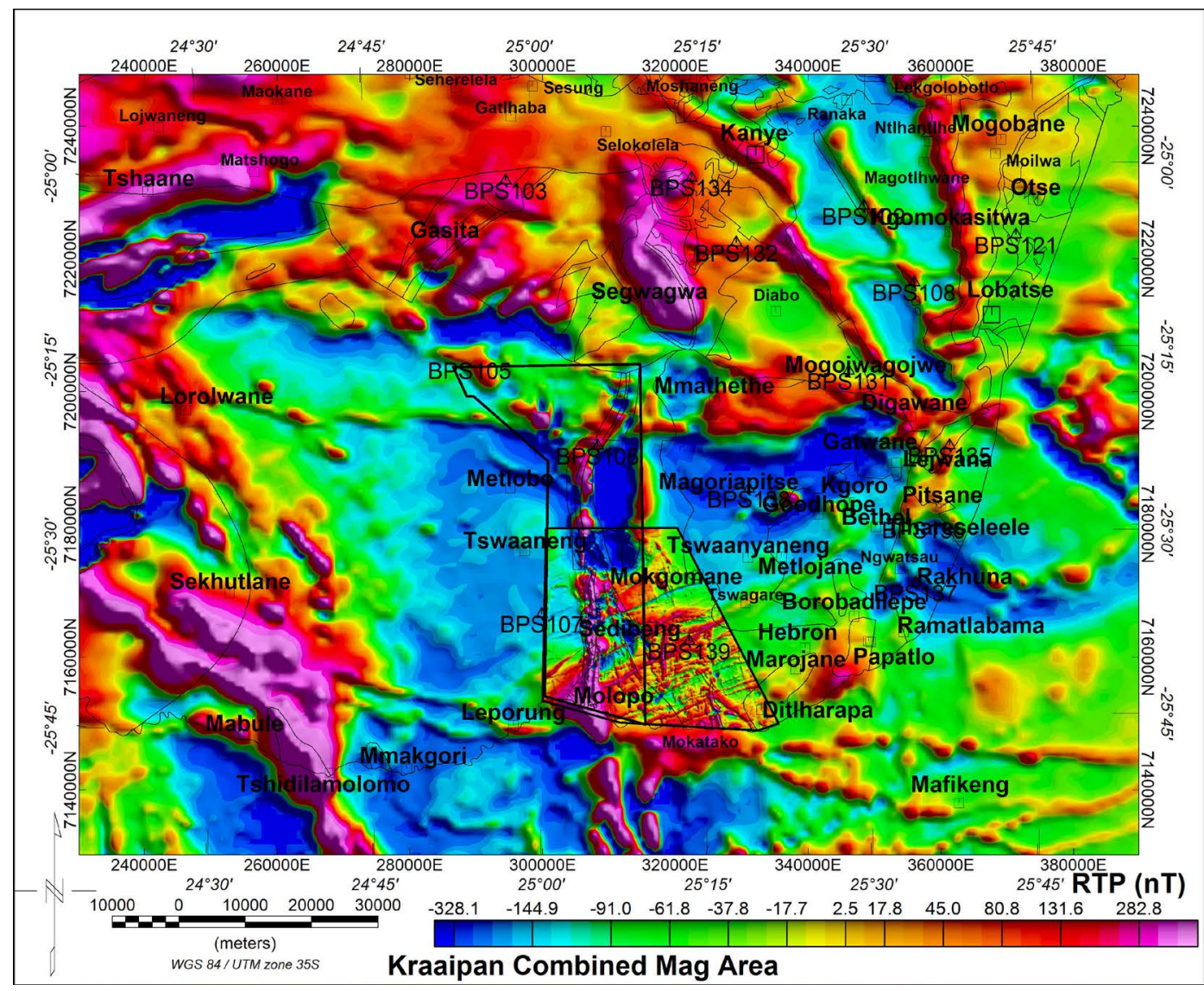

Figure 4. Regional IGRF corrected colour-shaded aeromagnetic data of the study area, showing several structural trends representing BIF horizons, dykes and faults. (Red = magnetic high; Blue = magnetic low) Blocks show high resolution aeromagnetic data coverage (e.g., Figure 5) for mineral exploration. 
thick banded iron formations (BIF) which have strong aeromagnetic signatures and which can thereby be followed along strike for considerable distances from their outcrop in the south west of Sedibeng (Figure 4). The two major magnetic anomalies (approximately $180 \mathrm{~km}$ in length) trend nearly N-S direction. The southeastern part (mainly in South Africa) is occupied by a series of elongated and relatively higher magnetic intensities trending in an EW-to-ENE direction (good examples around Mafikeng), cross-cut by N-S lineaments of the Kraaipan BIF in the centre of the map (Molopo). The northeastern corner is marked by three nearly NW-SE trending lineaments/features of moderate to high positive magnetic intensities centered around Kanye, Ranaka and Lekgolobotlo but converging around Digawana.

The high resolution aeromagnetic (HRAM) data (Figure 5) show that the southeastern area is marked by NE-SW-trending high-frequency, short wavelength positive magnetic intensities, corresponding to a Proterozoic dyke swarm and faults or other lineaments [1]. Based on this map, the Kraaipan BIF is clear

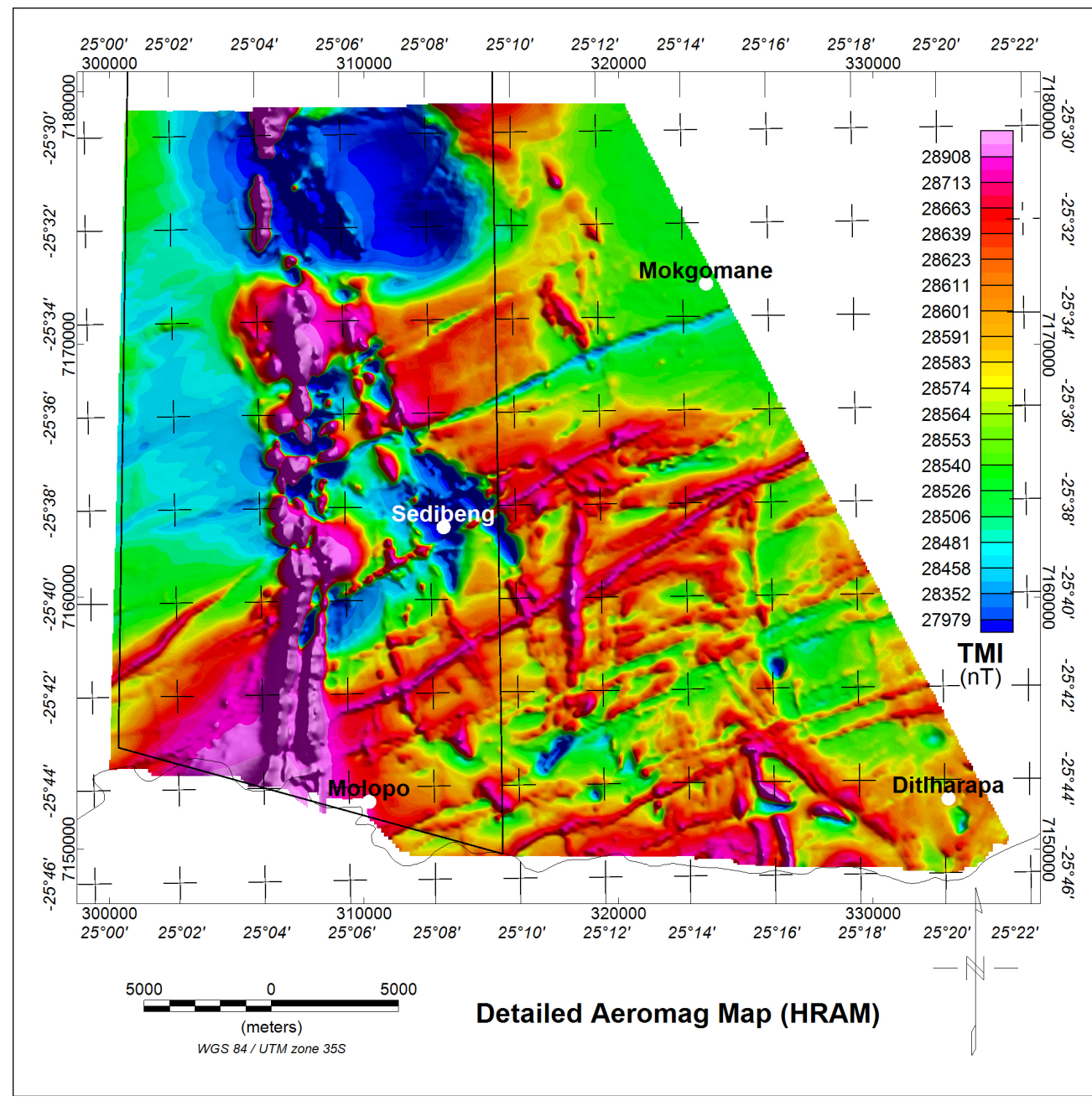

Figure 5. Detailed total magnetic intensity (TMI) colour-shadow map of exploration area showing the N-S trending BIF and NE-to-ENE-trending dykes and faults. Box indicates further higher resolution mineral exploration area (magnetic, electromagnetic, radiometric data). 
for over $30 \mathrm{~km}$ from west of Molopo. All these structures are further elucidated in the processed maps and their hydrogeological significance discussed later.

\subsection{Gravity Data and Geological Correlation}

The gravity data used in this study are described in detail by [1] and the station distribution and simple Bouguer gravity anomaly grid are shown in Figure 6. A total of one hundred and forty (140) new gravity data points were collected, merged with other existing gravity data, and then used to construct the gravity map of the study area, which is generally dominated by a broad high. More data are currently being acquired to improve the regional station coverage/density.

The gravity maps (e.g., Figure 6) indicate that the Kraaipan greenstone rocks correlate with a major NS-trending gravity high (at Molopo, Tswaaneng and Metlobo villages), and is believed to be caused by magnetite quarzites, banded iron formations and metavolcanic rocks [1]. Their peak values reach over -90 $\mathrm{mGal}$, which is the strongest anomaly within the study area. Other notable highs occur over (are coincident with) the Segwagwa Complex and between Goodhope and Mmathethe in the central part, and over the Molopo farms (ultramafic) complex in the west (south of Lerolwane). The Bouguer anomaly map observations

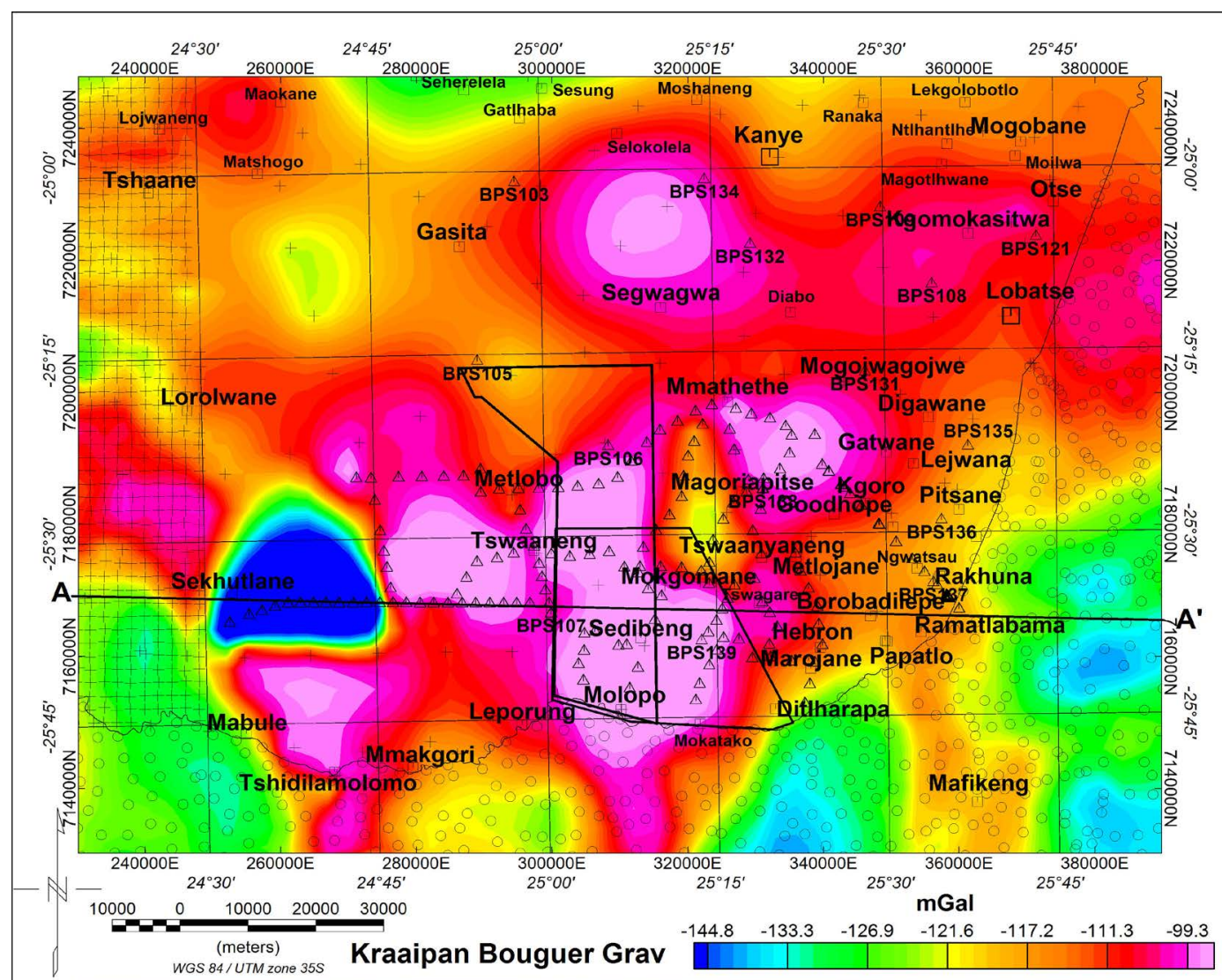

Figure 6. Simple Bouguer gravity anomaly grid/map and actual distribution of gravity stations (+ is for existing data in Botswana acquired from Geological Survey, circle represents gravity points in South Africa and triangle represents gravity data acquired in this study. Location of profile A-A' modeled for subsurface geological sections (Figure 7) is indicated. 
(Figure 6) thus support the aeromagnetic anomaly maps (Figure 4 and Figure 5). There are several gravity lows with peak magnitudes of $-123 \mathrm{~m}$ Gals also recognized in this map. The map reveals prominent gravity lows in circular and oval shapes distributed at the central and southern parts of the mapped area. It is clearly observed from several gravity maps that meta-clastic rocks at Sekhutlane village have low gravity intensities. Moreover, the results of this study show more extent and new granitoid intrusions than the previous geological mapping.

South of the study area in South Africa, three linear (and narrow) gravity highs correlate with the Madibe ( $M$, around Mafikeng), Kraaipan (K) and Stella (S) greenstone belts (Figure 6), dominated by mafic metavolcanic rocks interlayered with ferruginous and siliceous metasedimentary rocks, mainly BIF and ferruginous chert [1]. These are bounded by a series of moderate to low gravity anomalies resulting in a typical volcanic-granitic gravity character, with multiple small blocks, high gradients and quick succession of positive and negative anomalies.

\section{Geophysical Results and Interpretation}

As basement heterogeneities should affect both gravity and magnetic fields, we are preferentially looking for collocated contrasts in both of these fields. However, it should be noted that regional gravity data are commonly used to delineate the position of boundaries at deeper levels than aeromagnetic data [1] [27]. The following results summarise the most significant gravity and magnetic anomalies of which at least some should represent basement faults or other significant structures within the Kraaipan granite-greenstone terrain which are of importance to groundwater exploration.

\section{1. $23 / 4$ D Gravity Modelling and Sediment Thickness}

The configurations of the main geological units in the study area were determined along one selected regional profile (see Figure 6 and Figure 7) with data sampled from the Bouguer gravity map along a detailed field traverse $(\sim 2 \mathrm{~km}$ spacing). The density contrast values for the various rock units and the basement were estimated from [27] [52] [53] and [54]. A regional gravity structural cross-section (Figure 7) was derived/obtained using GM-Sys' $23{ }_{4}^{3} \mathrm{D}$-forward modelling technique. The gravity field was calculated iteratively for these geological models, until a good fit was reached between the observed (dots) and calculated (line) profiles. Different density values (within the standard deviation of $\pm 30 \mathrm{~kg} / \mathrm{m}^{3}$ ) were tested but these did not significantly change the shapes and depth extents of the units, as noted/observed by others [54] [55].

The modelling results show that the sediment thickness and/or depth to (granitic) basement is at most $60 \mathrm{~m}$, with the largest values in the west (Figure 7). Newly mapped granitic plutons on the Bouguer anomaly map (Figure 6) are also indicated. 


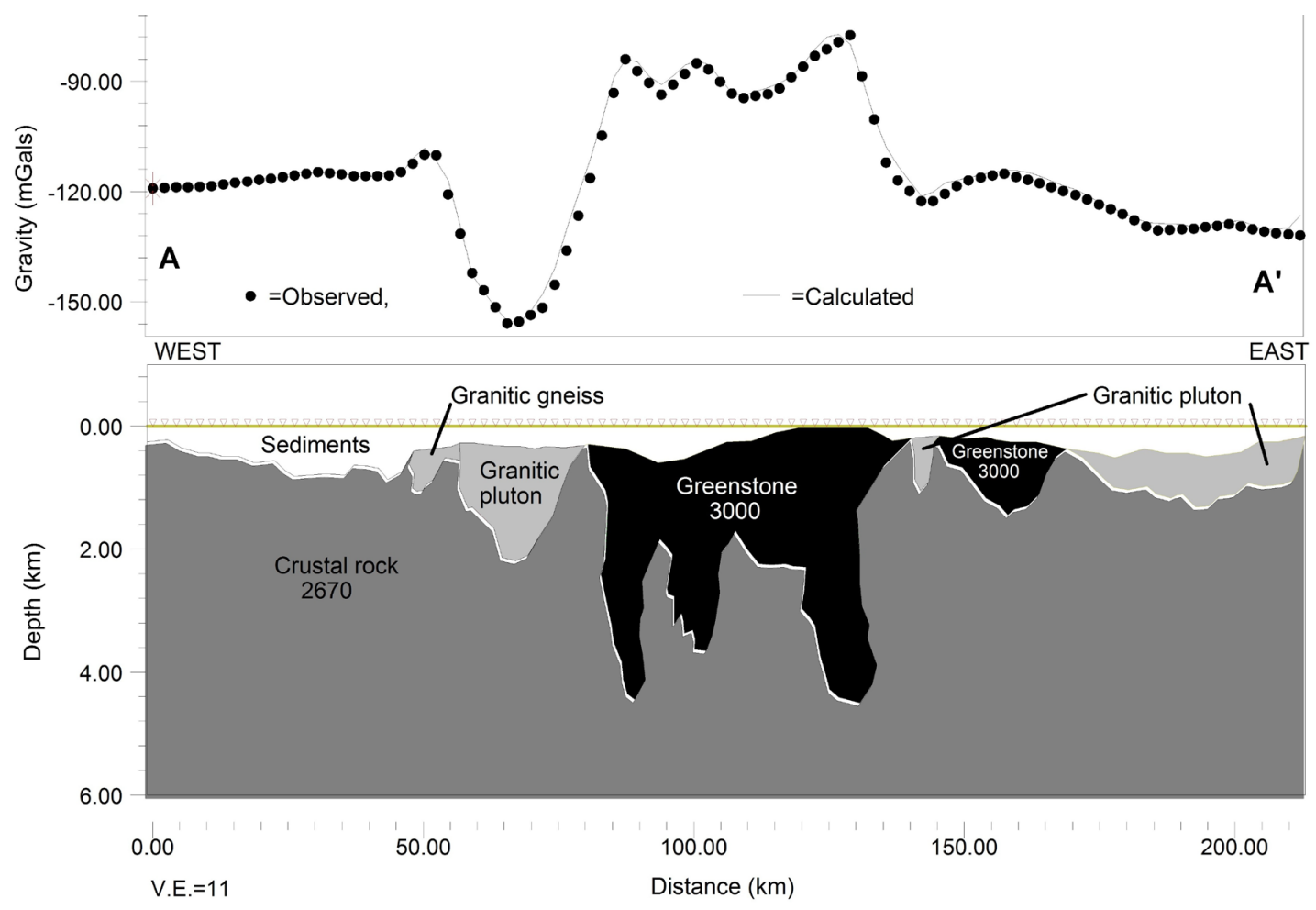

Figure 7. Kraaipan greenstone belt $2^{3} /{ }_{4} \mathrm{D}$ gravity model along profile A-A' (see Figure 6). The numbers inside the model bodies are densities in $\mathrm{kg} \mathrm{m}^{-3}$. Densities not shown are for sediments $2500 \mathrm{~kg} \mathrm{~m}^{-3}$, granitic pluton $2620 \mathrm{~kg} \mathrm{~m}^{-3}$ and granitic gneiss $2750 \mathrm{~kg} \mathrm{~m}^{-3}$. Vertical Exaggeration (V.E) $=11.0$.

\subsection{Depth to Susceptibility Discontinuities}

The application of depth determination techniques, to determine the subsurface layer thicknesses and estimate depth to top of the causative geological bodies, is one of the most important parameters that must be outlined in order to interpret adequately the geology and structure of the area. Here, two techniques are used to calculate the depths of the causative bodies utilizing the magnetic data: spectral frequency analysis and 3D Euler deconvolution method.

\subsubsection{Source Depth Estimates from Magnetic Spectra \\ Subsurface Geology: Layers \& Thicknesses}

The Fast Fourier Transformation (FFT) was applied on the RTP aeromagnetic survey data and a two-dimensional (radially averaged) power spectrum curve obtained (Figure 8). Four main average ensample interfaces at depths of $0.3 \mathrm{~km}$ (S4), $0.5 \mathrm{~km}$ (S3), $0.86 \mathrm{~km}$ (S2) and $2.85 \mathrm{~km}$ (S1) are revealed for shallowest layer, intermediate sources and for the deepest ensemble, respectively.

The first two shallowest depths are the most significant as they map thickness of sediments and/or the weathered zone (depth to magnetic basement) important for groundwater accumulation/storage.

\subsubsection{Depths from Euler Deconvolution of Magnetic Data Structural Mapping and Depth Estimates}

The Euler deconvolution technique was carried out on the magnetic data using 


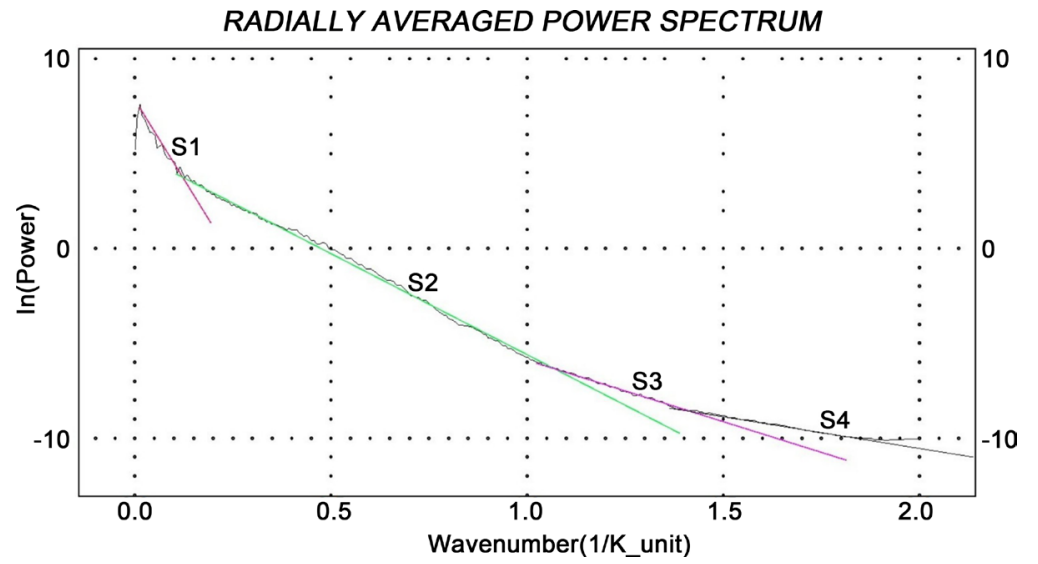

Figure 8. Radially averaged power spectrum of the regional RTP aeromagnetic data. The depth to a statistical ensemble of sources is determined from the expression: slope $=-4 \pi \mathrm{h}$ [51].

Geosoft program (Oasis montaj 8.2). Structural indices SI $=0,1$ and 2 and window size of 12 grid cells $(3000 \mathrm{~m}$ ) were used for interpreting contacts, faults and other curvilinear source types [49] [50]. The Euler solution at different depths for SI $=0$ is shown in Figure 9. The depths to the detected structures range between $0.0 \mathrm{~m}$ (outcropping) and just below $350.0 \mathrm{~m}$, which is also expected for a window size of $400 \mathrm{~m}$.

Several linear features indicated on the RTP colour-shadow map (Figure 5) are now clearly evident, with the boundaries of the primary elements and major domains clearly recognized in the Euler depth map (Figure 9). New structures are also evident, and their locations and depths confirmed.

\section{Discussion}

Over any area of past or present active tectonics, surface structural alignments are often visible as expressions on topographic, geologic and geophysical maps. These lineaments become less distinct with age but are still important as indicators of past stresses, displacements, and disturbance patterns significant for groundwater transport (recharge) and storage/accumulation. Because the buried sediment-basement contact is not affected by erosion, these structural patterns remain imprinted in it and could be revealed from potential fields. Alignment of anomalies in geophysical maps provides important information for structural analysis; however, it still remains an open question whether all or most magnetic and gravity lineaments correspond to basement faults, folds, or other structural patterns important for exploration.

As stated in the earlier sections, results from the enhanced aeromagnetic data and merged gravity data conform well with the previous field geological mapping, specialized geochronological, geochemical and petrological sampling by several geoscience pioneers [17] [18] [19] [20]. However, these enhanced merged data together with existing aeromagnetic data yield more essential geological information, particularly those regarding contexts of tectonism and 


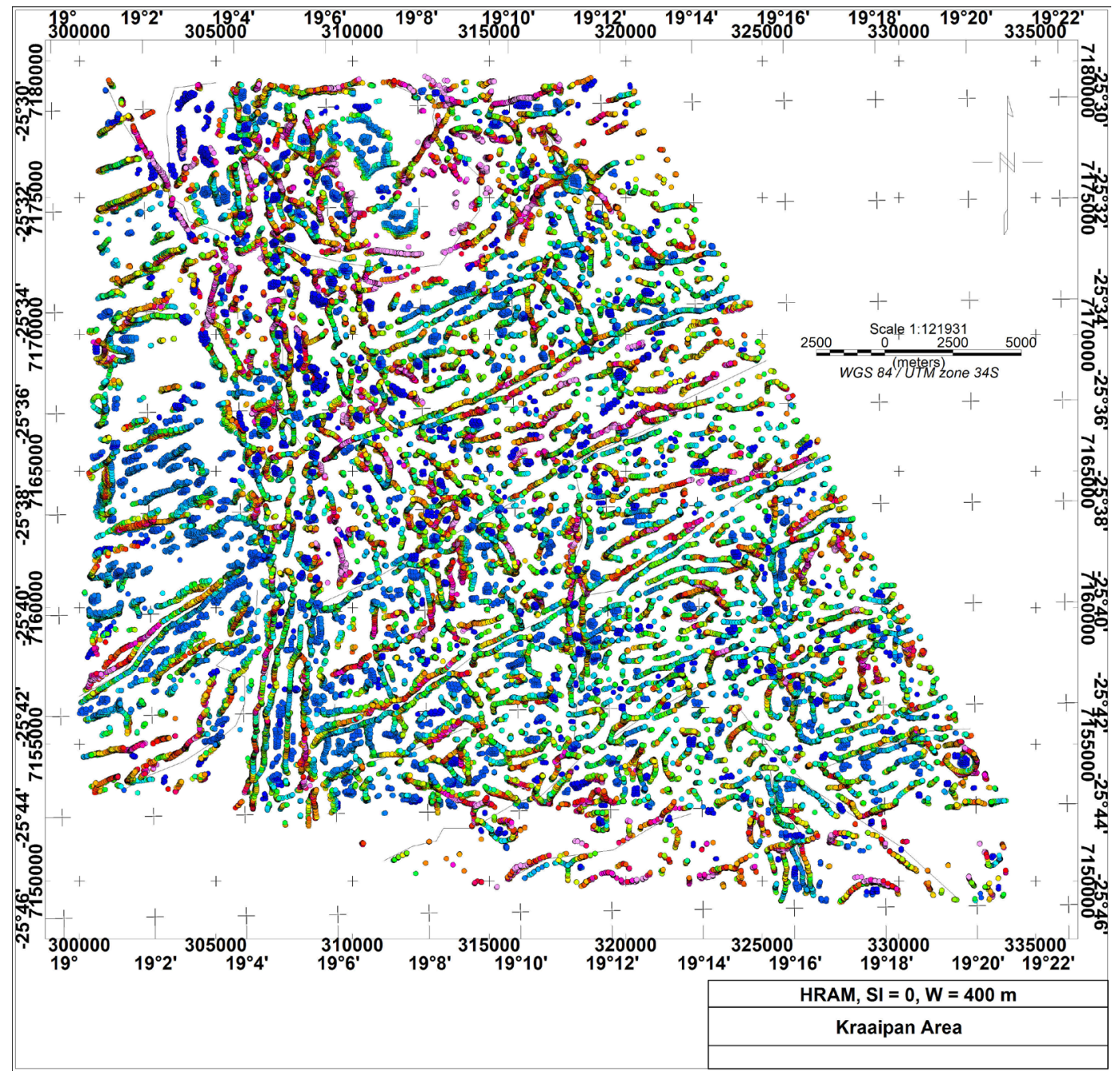

Figure 9. Euler deconvolution solutions for high resolution aeromagnetic data for $\mathrm{SI}=0(\mathrm{~W}=400 \mathrm{~m}) \mathrm{em}$ phasizing shallow $(\leq 350 \mathrm{~m}$ ) linear features. This SI is applicable to both finite and infinite contact/fault in magnetics [49] [50].

mineral/groundwater exploration. First, as suggested by [1], two major gravity and magnetic highs coincide with the western and central greenstone belts caused by magnetite and quarzites, banded iron formations and metavolcanic rocks. Second, and more importantly, the applied processes/techniques have yielded subsurface layer thicknesses as well as location and depths of the several structures.

In this discussion, special emphases are placed on the relationship of the interpreted gravity and airborne magnetic data to geology and structure of the Kraaipan greenstone terrain and their application to groundwater exploration.

\subsection{Borehole Depth in Relation to Gravity and Magnetic Basement}

The borehole depths were gridded using a minimum curvature technique resulting in a grid reflecting water strike depth ranges for the study area (Figure 10), interpreted to be depth to water table. The western part/third of the area 


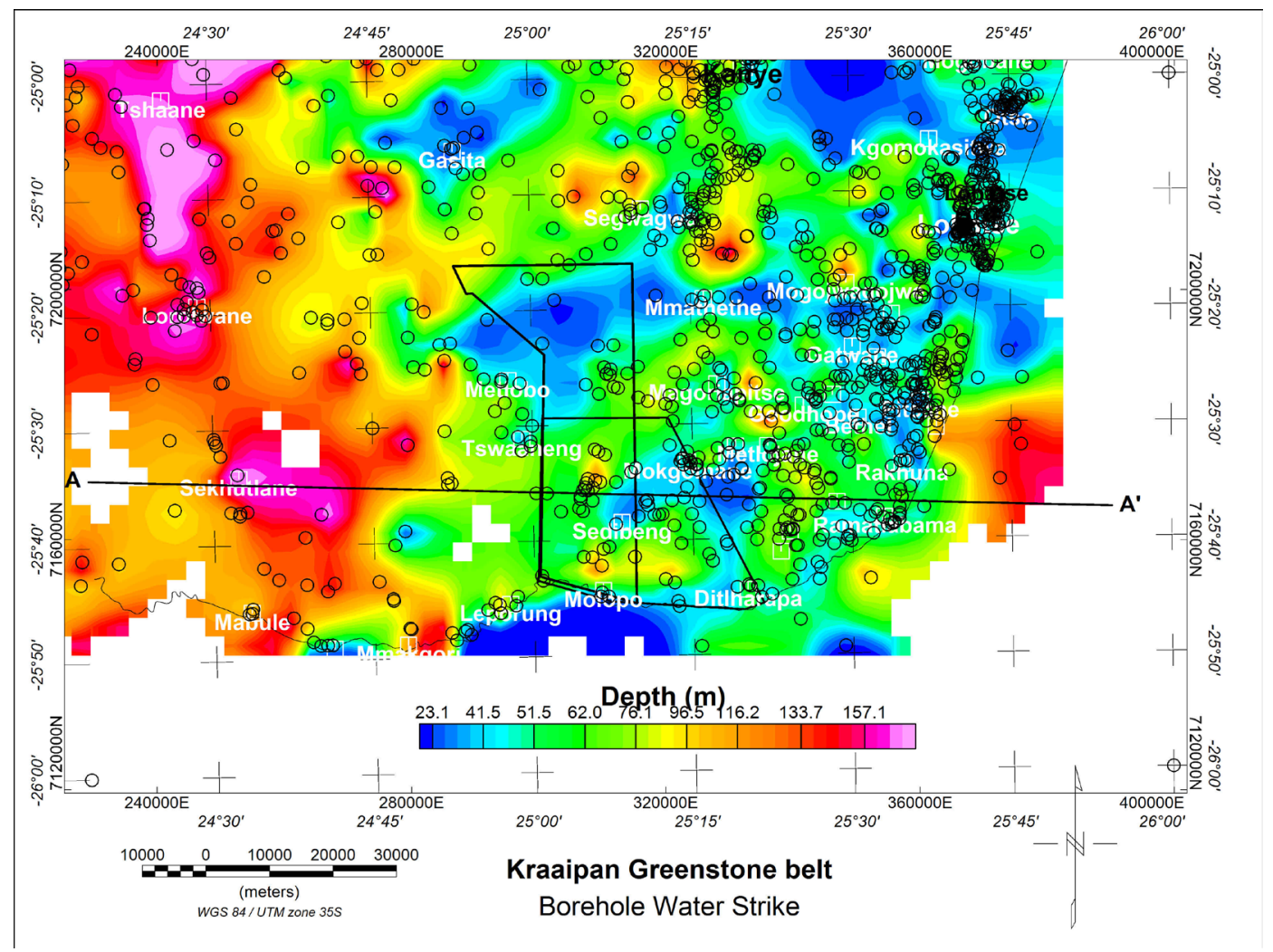

Figure 10. Gridded borehole water strike depth reflecting water level in different aquifers, indicating relatively shallow levels in the eastern half (karst) and deep in the west (sedimentary?). Location of profile A-A' modeled for subsurface geological sections (Figure 7) is indicated.

constitutes sedimentary aquifer with deep water table, followed by central area of granite-gneiss with mixed levels and then fairly shallow water table in the karst (dolomite) aquifer in the northeast.

\subsection{Borehole Yield in Relation to Aquifer Types and/or Compartments/Units}

The various observed and/or interpreted gravity and magnetic zones and structures correspond to different aquifer types or units (e.g., Figure 2) as alluded to above. There are high magnetic field intensities observed at both western and central zones of the study area, so the linear magnetic bodies in these zones suggest that these features are caused by intrusive rocks which correspond well with several of the known granitoid rocks comprising tonalitic and trondhjenilitic gneisses, granodiorites and adamelites with BIF horizons. Narrow and higher amplitude magnetic anomalies in western and the central parts coincided with gravity highs, particularly at Phitshane-Molopo and Mabule, suggest the existence of mafic volcanic rocks. Field investigation reveals that the rocks in these areas are made up mainly of banded iron formations (BIF), magnetite quartzites and metavolcanic rocks [19]. The borehole yields (Figure 3) were also gridded using a minimum curvature technique resulting in a relatively smooth grid (Figure 11) for correlation with the gravity and magnetic zones and structures. 


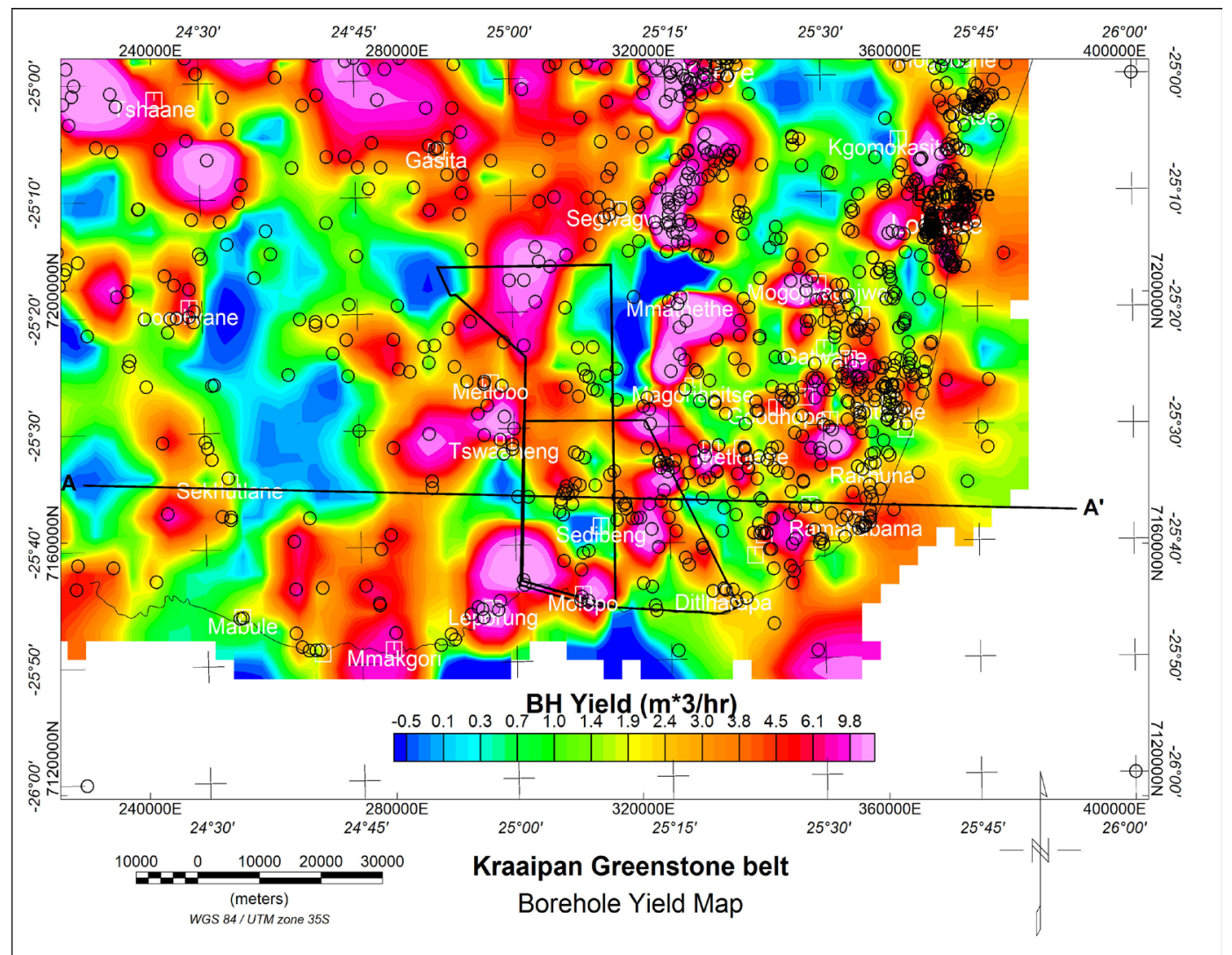

Figure 11. Borehole yield grid in relation to known/interpreted aquifer types and/or compartments. Note the NNE-trending zone of high yields in the central part of the area/map. Location of profile A-A' modeled for subsurface geological sections (Figure 7) is indicated.

The extreme northern area of partly exposed granitic-gneiss terrain (hard rock aquifer) corresponds to high yields. The central area depicts two conspicuous NS-trending linear belts of high yields over the main BIF while the southeast area is characterised by moderate to high yields. The west-central part mainly covered by the Kalahari sands (sedimentary aquifer) surprisingly shows the lowest yields (Figure 11). This is attributed to the relatively thin $(\leq 60 \mathrm{~m})$ sedimentary cover as derived from the modelling (Figure 7). However, the extreme western study area corresponding to metalvolcanic and ultramafic rocks (Molopo farms complex) also suggests a NS-trending zone of high yields. The known karst aquifer (Ramotswa aquifer) around the Otse-Lobatse area is also reflected as a high yield zone (as expected). Overall, the map can be used to prioritise further exploration zones.

\subsection{Borehole Yields in Relation to Structural Features}

In this study, extraction of the geological structures and smaller-scale lineaments was based on combining multiple data attributes. Our lineament extraction mostly relied on transformations of the magnetic and gravity fields that included the vertical and horizontal gradients, analytic signal and several variants of local wavenumber mapping. Among these methods, the vertical gradient (Figure 12) 


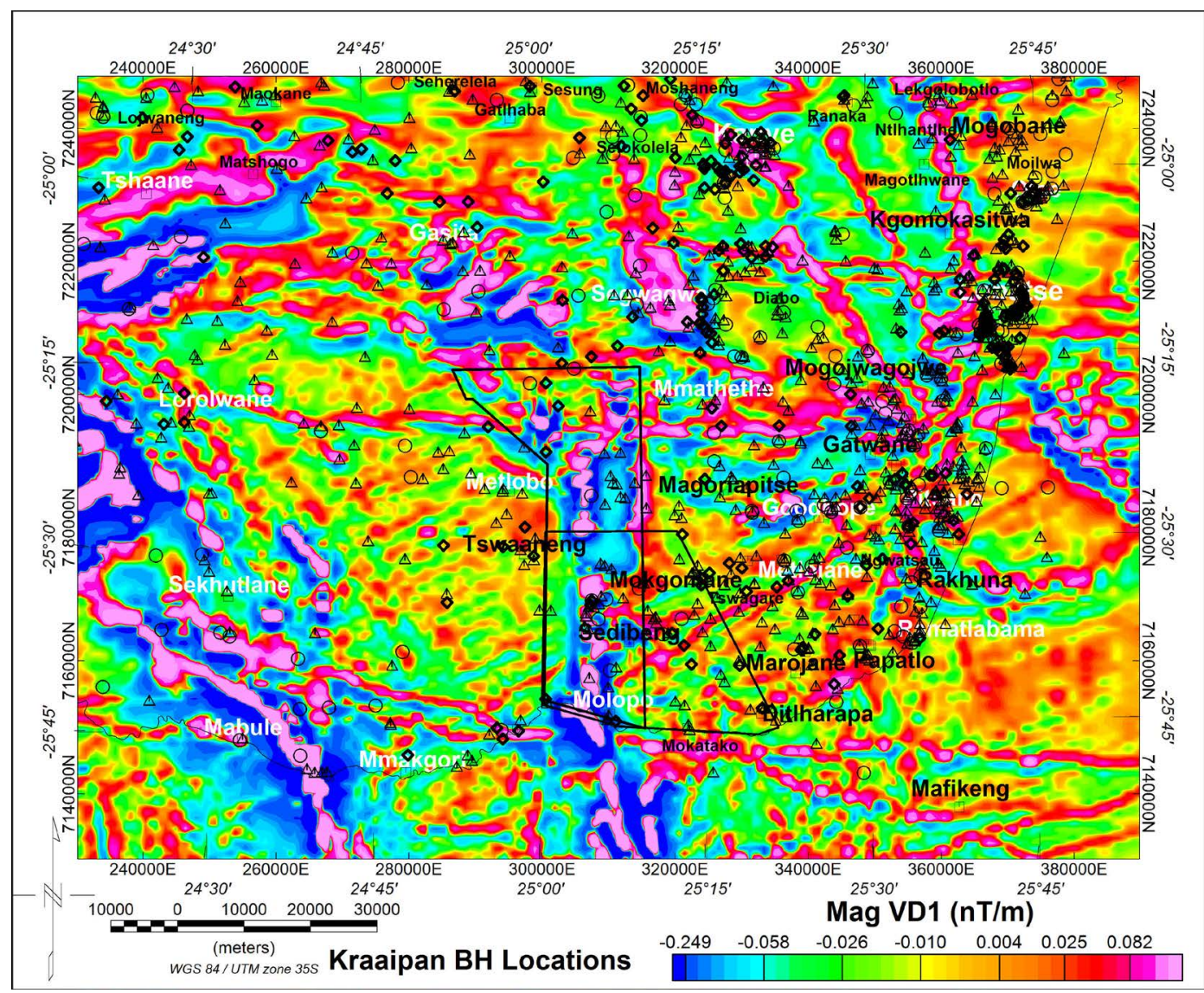

Figure 12. Existing borehole yield classifications in relation to aeromagnetic first vertical derivative structures $\left(\Delta=\right.$ low yield range: $1-5 \mathrm{~m}^{3} / \mathrm{hr}$; o = medium/average yield range: $6-9 \mathrm{~m}^{3} / \mathrm{hr}$, and $\diamond=$ high yield range: $10-160 \mathrm{~m}^{3} / \mathrm{hr}$ ).

and analytic signal were the most important. Thus the initial pattern of the lineaments was drawn mainly based on the vertical gradient contrasts, followed by and their refinement using other attribute maps extracted from the magnetic and gravity fields. By combining the observations from various attribute maps and reducing the effects of noise and processing artefacts, an interpretation map of the high resolution aeromagnetic data depicting major lineaments was obtained (Figure 13).

The study area is basically dominated with lineament features which can be confidently recognized from the magnetic data (Figure 4, Figure 5, Figure 9 and Figure 12). The magnetic anomalies display several trends defined by alignment of intensities, gradients and shapes of anomalies, and are best illustrated in Figure 9 and Figure 12. The most prominent magnetic lineaments crossing the entire Madibe-Kraaipan terrain are at Eastern part of the survey area. These structures change their trends from NW-SE in the northeast to NE-SW and $\sim$ EW in the south of the study area (Figure 12$)$. The latter $(\sim \mathrm{EW})$ regional structures discernable across the entire study area appear to be older than the others based on cross-cutting relations, and overprinting of the basement blocks of different tectonic origins and potential-field signatures (Figure 4). 


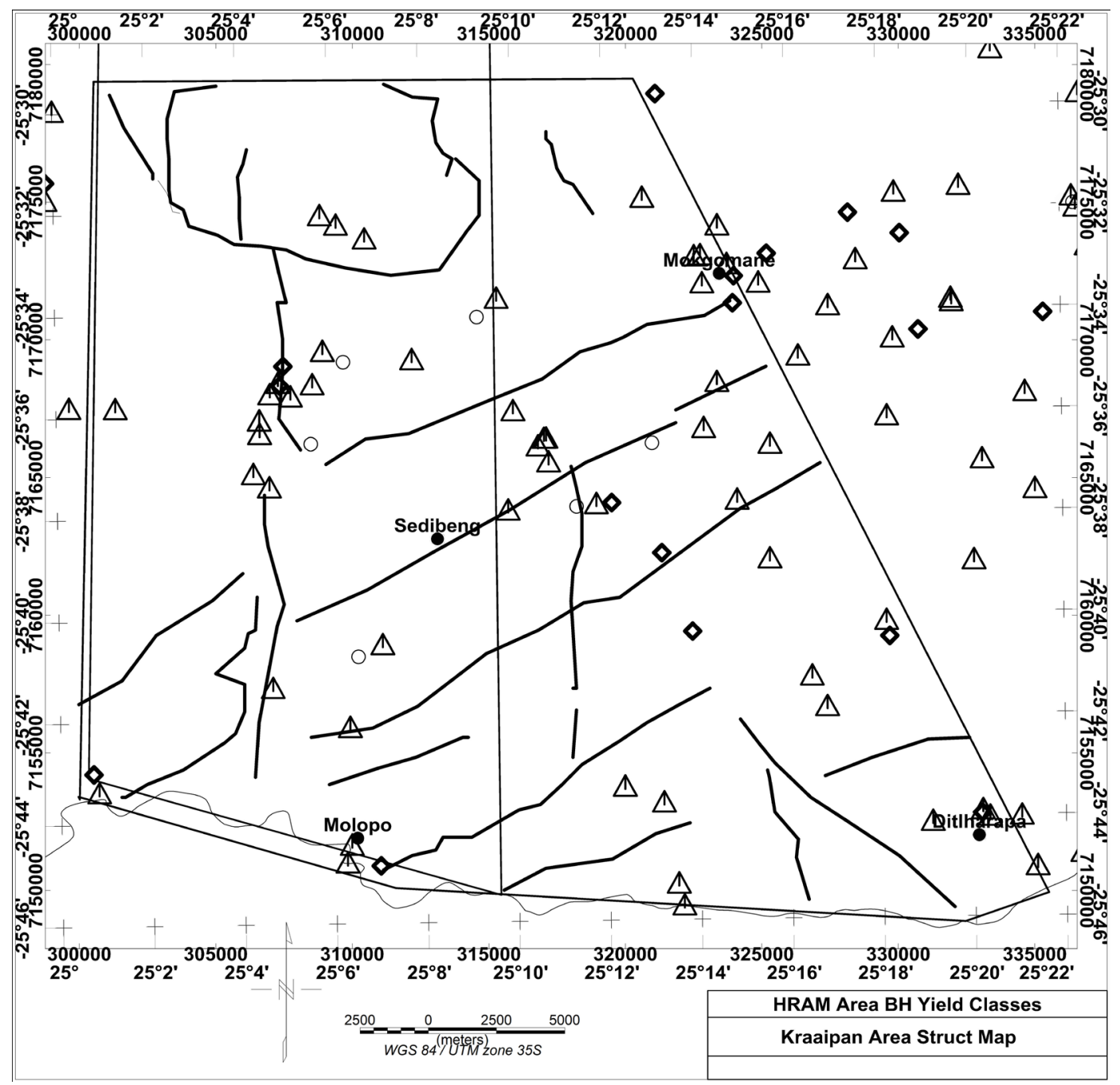

Figure 13. Existing borehole yield classifications in relation to interpreted aeromagnetic structures for HRAM area $\left(\Delta=\right.$ low yield range: $1-5 \mathrm{~m}^{3} / \mathrm{hr}$; o = medium/average yield range: $6-9 \mathrm{~m}^{3} / \mathrm{hr}$, and $\diamond=$ high yield range: $10-160 \mathrm{~m}^{3} / \mathrm{hr}$ ). Clearly, boreholes with low yield range are the majority.

The aeromagnetic maps show the long continuity of lineaments of the moderate to high amplitude anomalies with the roughly north-south direction in the central zone corresponding to the greenstone (BIF) structure in geologic maps [17] [19] [20]. The north-south structure is cross-cut by the east-trending lineaments. This result is in good agreement with the regional structure reported earlier by previous authors, which showed the correlation of the regional structure with the geochemical and petrological data [17] [19] [20].

We considered whether such structures could be potentially related to faulting associated with basement rocks and thus open for groundwater recharge or in-filled dykes acting as groundwater barriers. The classified existing borehole yields (Figure 3) were thus overprinted on the magnetic vertical derivative map (Figure 12) and the dominant lineaments interpreted from the HRAM data (Figure 13). On a regional scale, most of the high yield boreholes $\left(>10 \mathrm{~m}^{3} / \mathrm{hr}\right)$ are associated with magnetic structures or features. It is evident from Figure 12 and Figure 13 that 
there is very little correlation between borehole positions and geophysical structures. However there is some correlation between medium to high yield boreholes and some of the major structures.

\subsection{Data Synthesis}

A synthesis of the various maps is presented in Table 3 based on the composite presentation in Figure 14 below, and both help define the best groundwater potential zones (A, B, C in order of priority).

\section{Conclusions and Recommendations}

Kraaipan granite-greenstone geophysical and hydrogeological data from South-East Botswana have been processed and interpreted. The results of the magnetic and gravity methods used revealed that the lithologies and tectonic framework of the Archaean basement rocks extend into Southeast Botswana from South Africa. In particular, the derivative, analytic signal and Euler deconvolution maps reveal the complex geological structure of the terrain and basement rocks suitable for groundwater potential assessment.

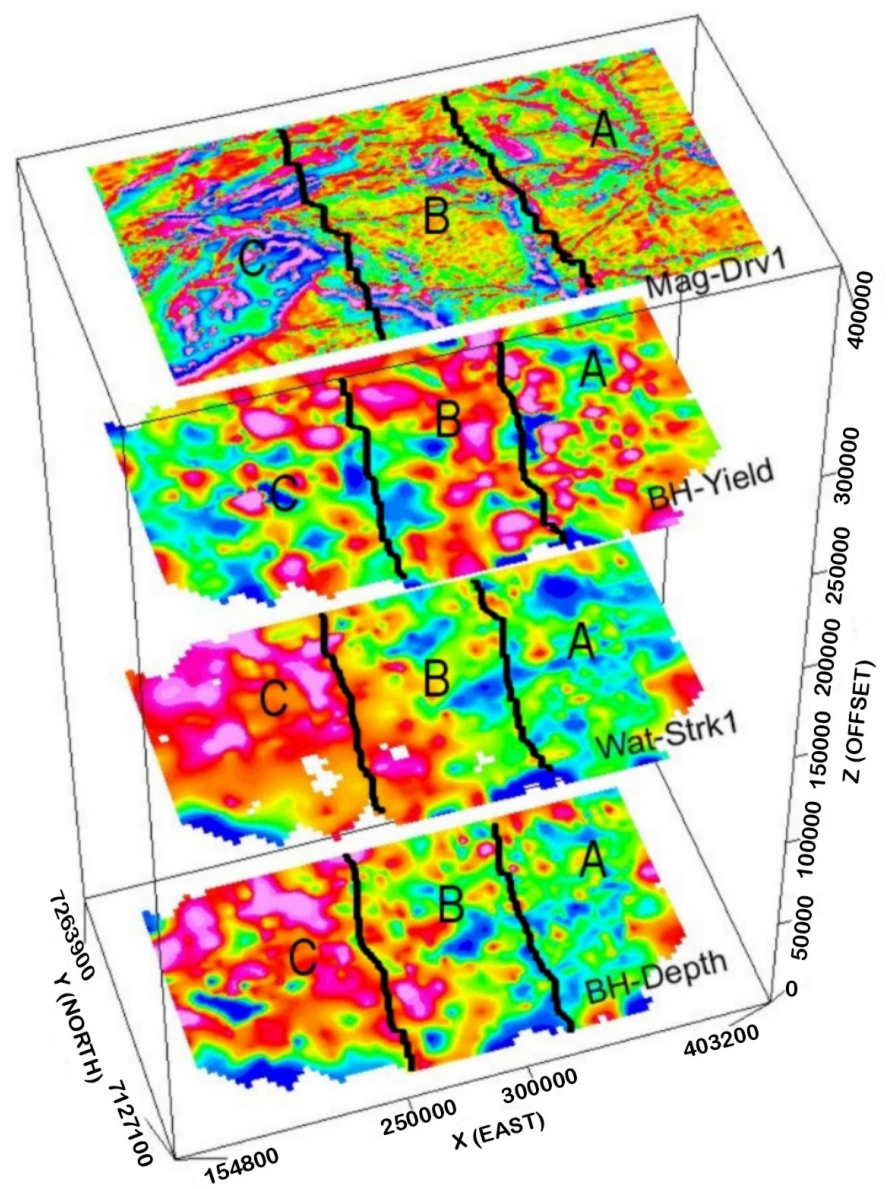

Figure 14. 3D composite map display of the magnetic first vertical derivative, borehole yield, water strike depth and total depth (highest values in red/purple down to lowest values in deep blue) for direct correlation of these variables (Table 3). 
Table 3. Summary hydrogeophysical variables and characteristics: groundwater potential zones.

\begin{tabular}{|c|c|c|c|}
\hline $\begin{array}{l}\text { Hydrogeophysical } \\
\text { Variable/Parameter }\end{array}$ & Zone A & Zone B & Zone C \\
\hline MagDrv1 & $\begin{array}{l}\text { Several lineaments at various } \\
\text { angles, highly fractured }\end{array}$ & Magnetically quiet, few $\sim \mathrm{E}-\mathrm{W}$ lineaments & $\begin{array}{l}\text { Some linear to curvi-linear } \\
\text { features, mostly magnetic low }\end{array}$ \\
\hline Yield & Fair to high borehole yield & $\begin{array}{l}\text { NNE-trending zone of high borehole yield, } \\
\text { flanked by low zone to the west }\end{array}$ & $\begin{array}{l}\text { Poor to locally fair or } \\
\text { intermediate }\end{array}$ \\
\hline Water Strike & Shallow; high water table & $\begin{array}{l}\text { Generally shallow water strike flanked by deep } \\
\text { zone coincident with low yield }\end{array}$ & $\begin{array}{l}\text { Mostly large depth, consistent } \\
\text { with sand cover }\end{array}$ \\
\hline BH Depth & Shallow & Intermediate/moderate to large depths & $\begin{array}{l}\text { Mostly large depth, consistent } \\
\text { with sand cover }\end{array}$ \\
\hline $\begin{array}{l}\text { Aquifer Type; } \\
\text { Comments }\end{array}$ & Karst/dolomite and volcanic & Mostly granite-gneiss, intruded by N-S BIF & $\begin{array}{l}\text { Mostly granite-gneiss under } \\
\text { thick Kalahari sands }\end{array}$ \\
\hline
\end{tabular}

Three main regions with different internal structural patterns and hydrogeological characteristics were deduced: 1) eastern zone dominated by NW-SE and NE-SW features; 2) central crystalline zone with mainly E-W structures and the major N-S BIF horizon; and 3) western sedimentary zone marked by NW-SE to WNW-ESE lineaments (Figure 12 and Figure 14, Table 3). However, the $\sim$ E-W magnetic lineament structures appear to cut across the entire study area. The area is dissected by an ENE-to-EW-trending Proterozoic dyke swarm visible on the high resolution aeromagnetic data (Figure 5 and Figure 13), and associated with the initial crustal faulting.

The results of the depths interpretation indicate that the rocks are under $>50$ $\mathrm{m}$ of Kalahari cover and the study area is composed of three aquifers: the extensive hard rock aquifer (granitic and volcanic), the important (fractured) karst aquifer and the minor sedimentary aquifer. Spectral analysis reveals three main average ensample interfaces at depths of $0.7 \mathrm{~km}, 1.99 \mathrm{~km}$ and $4.8 \mathrm{~km}$. The linear Euler solutions maps reveal that the majority depths to top of magnetic bodies range from $40 \mathrm{~m}$ to $400 \mathrm{~m}$ throughout the survey area. The shallowest depths are the most significant one for groundwater as they probably relate to depth of bedrock and thickness of regolith or thickest sediments.

For 2695 existing boreholes analysed, maximum borehole depth is $482 \mathrm{~m}$ (mean $108 \mathrm{~m}$ ), and almost half (1263) were dry with another 972 having low yield (1 - 5 $\mathrm{m}^{3} / \mathrm{hr}$ ) and 432 yielding $6-49 \mathrm{~m}^{3} / \mathrm{hr}$ and only 28 above $50 \mathrm{~m}^{3} / \mathrm{hr}$ (maximum $\sim 160 \mathrm{~m}^{3} / \mathrm{hr}$ ) and an average water strike of $64 \mathrm{~m}$. Finally, all geophysical results were jointly evaluated and the most promising locations for positioning the hydro-wells were proposed. An analysis of various types of aquifers shows that the shallow fractured-karst aquifers can be described as very good, the shallow fractured crystalline and metamorphic aquifers as good, while the deep sedimentary aquifers are fair, in terms of quantity of groundwater. The main results and conclusions can be summarised as follows:

1) Identified dykes, faults, joints, zones of weathering and sediment thickness.

2) Correlation of structural map with hydrogeological and drill hole information. 
3) Very little correlation between interpreted hydrogeophysical features and the existing borehole locations.

4) Shallow fractured-karst aquifers $\rightarrow$ very good; but prone to pollution (e.g., pit latrines).

5) Fractured crystalline and metamorphic aquifers $\rightarrow$ good (moderate depth and cost).

6) Deep sedimentary aquifers $\rightarrow$ fair (expensive/costly; possibility of brackish water due to poor circulation) [3] [12] [56].

In conclusion, the study shows the importance of preliminary geophysical investigations before ground borehole siting and drilling in order to improve borehole success rates and/or reduce costs. The described exploration scheme takes into account the fact that the end-users usually require that geophysical survey cost must be only a small portion of the total hydro well construction budget. This study revealed that had the geophysical data analysis been available at the time of siting and drilling it would have guided the drilling programme and substantially reduced the number of dry boreholes and hence saved financial resources.

Further studies are planned to include determination of aquifer hydraulic properties [4] [6] [10] [57] and recharge issues-geochemistry/isotopes [4] [12] [56] which are beyond the scope of this paper but within the overall project/research goals. This will assist the sustainable management of the aquifers in this era of climate change [2].

\section{Acknowledgements}

Sincere thanks to Department of Geological Survey of Botswana and Department of Water Affaires for providing the existing geophysical data and borehole data, respectively. The work was financially supported by Office of Research and Development (ORD) of University of Botswana-Grant R0699. The reviewers' critical comments and the editor's suggestions are greatly appreciated as they improved the paper.

\section{References}

[1] Ramotoroko, C.D., Ranganai, R.T. and Nyabeze, P. (2016) Extension of the Archaean Madibe-Kraaipan Granite-Greenstone Terrane in Southeast Botswana: Constraints from Gravity and Magnetic Data. Journal of African Earth Sciences, 123, $39-56$.

[2] Gorelick, S.M. and Zheng, C. (2015) Global Change and the Groundwater Management Challenge. Water Resources Research, 51, 3031-3051.

https://doi.org/10.1002/2014WR016825

[3] Ranganai, R.T., King, J.G., Koosimile, D.I. and Ngwisanyi, T.H. (2003) Geophysical Methods for Groundwater Resources Assessment, Development and Pollution Mapping and Monitoring: Examples from Botswana and Zimbabwe. 4th WATERNET/ WARFSA Annual Symposium, Gaborone, 15-17 October 2003.

http://www.waternetonline.ihe.nl/aboutWN/4thProceedings3.htm 
[4] Araffa, S.A.S. (2013) Delineation of Groundwater Aquifer and Subsurface Structures on North Cairo, Egypt, using Integrated Interpretation of Magnetic, Gravity, Geoelectrical and Geochemical Data. Geophysical Journal International, 192, 94-112. https://doi.org/10.1093/gji/ggs008

[5] Zeil, P., Volk, P. and Saradeth, S. (1991) Geophysical Methods for Lineament Studies in Groundwater Exploration. A Case History from SE Botswana. Geoexploration, 27, 65-177.

[6] Murty, B.V.S. and Raghavan, V.K. (2002) The Gravity Method in Groundwater Exploration in Crystalline Rocks: A Study in the Peninsular Region of Hyderabad, India. Hydrogeology Journal, 10, 307-321. https://doi.org/10.1007/s10040-001-0184-2

[7] Ranganai, R.T. and Ebinger, C.J. (2008) Aeromagnetic and LANDSAT TM Structural Interpretation for Identifying Regional Groundwater Exploration Targets, South-Central Zimbabwe Craton. Journal of Applied Geophysics, 65, 73-83.

[8] Anbazhagan, S. and Jothibasu, A. (2014) Geoinformatics in Groundwater Potential Mapping and Sustainable Development: A Case Study from Southern India. $\mathrm{Hy}_{-}$ drological Sciences Journal.

[9] Roy, I.G. (2014) Multiscale Analysis of High Resolution Aeromagnetic Data for Groundwater Resource Exploration in an Arid Region of South Australia. Journal of Applied Geophysics, 105, 159-168.

[10] Monteiro Santos, F.A., Sultan, S.A., Represas, P. and El Sorady, A.L. (2006) Joint Inversion of Gravity and Geoelectrical Data for Groundwater and Structural Investigation: Application to the Northwestern Part of Sinai, Egypt. Geophysical Journal International, 165, 705-718. https://doi.org/10.1111/j.1365-246X.2006.02923.x

[11] Wright, E.P. and Burgess, W.G. (1992) The Hydrogeology of Crystalline Basement Aquifers in Africa. Geological Society Special Publication, London, 66, 264 p.

[12] De Vries, J.J., Selaolo, E.T. and Beekman, H.E. (2000) Ground Water Recharge in the Kalahari with Reference to Paleo-Hydrologic Conditions. Journal of Hydrology, 238, 110-123.

[13] Owen, R. and Dahlin, T. (2010) Inherited Drainage-Paleochannels and Preferential Groundwater Flow. Hydrogeology Journal, 18, 893-903.

https://doi.org/10.1007/s10040-010-0588-y

[14] Grauch, V.J.S. and Bankey, V. (2003) Aeromagnetic Interpretation for Understanding the Hydrogeologic Framework of the Southern Española Basin, New Mexico. U.S.G.S Open File Report 03-124.

[15] Hubbard, S.S. and Linde, N. (2011) Hydrogeophysics. http://escholarship.org/uc/item/11c8s8d4

[16] Binley, A., Hubbard, S.S., Huisman, J.A., Revil, A., Robinson, D.A., Singha, K. and Slater, L.D. (2015) The Emergence of Hydrogeophysics for Improved Understanding of Subsurface Processes over Multiple Scales. Water Resources Research, 51, 3837-3866. https://doi.org/10.1002/2015WR017016

[17] Anhaeusser, C.R. and Walraven, F. (1999) Episodic Granitoid Emplacement in the Western Kaapvaal Craton: Evidence from the Archaean Kraaipan Granite-Greenstone Terrain, South Africa. Journal of African Earth Sciences, 8, 289-309.

[18] Key, R.M. and Ayres, N. (2000) The 1998 Edition of the National Geological Map of Botswana. Journal of African Earth Sciences, 30, 427-451.

[19] Mapeo, R.B.M., Armstrong, R.A., Kampunzu, A.B. and Ramokate, L.V. (2004) SHRIMP U-Pb Zircon Ages of Granitoids from the Western Domain of the Kaapvaal Craton, Southeastern Botswana: Implications for Crustal Evolution. South African Journal of Geology, 107, 159-172. https://doi.org/10.2113/107.1-2.159 
[20] Poujol, M., Hirner, A.J., Armstrong, R.A. and Anhaeusser, C.A. (2008) U-Pb SHRIMP Data for the Madibe Greenstone Belt: Implications for Crustal Growth on the Western Margin of the Kaapvaal Craton, South Africa. South African Journal of Geology, 111, 67-78. https://doi.org/10.2113/gssajg.111.1.67

[21] Hammond, N.Q. and Moore, J.M. (2006) Archaean Lode Gold Mineralisation in Banded Iron Formation at the Kalahari Goldridge Deposit, Kraaipan Greenstone Belt, South Africa. Mineralium Deposita, 41, 483-503. https://doi.org/10.1007/s00126-006-0074-6

[22] Bagai, Z. and Odumetse, M.J. (2011) Mutiple Phases in the Mmathethe Granite in SE Botswana; Evidence for a Succession of Intrusive Episodes. 23 rd Colloquium of African Geology CAG23, Johannesburg, 10-14 January 2011, Abstracts Volume, 22.

[23] Aldiss, D.T. (1985) The Geology of Phitshane Area. An Explanation of Quarter Degree Sheets 2525C and 2525D Which Lies within Botswana. Bulletin of the Geological Survey, Botswana, 28, $106 \mathrm{p}$.

[24] De Vries, J.J. (1985) Hydrogeological Reconnaissance Map of the Republic of Botswana at Scale 1:500 000 (Sheet 11). Geological Survey Department, Lobatse.

[25] Cobbing, J.E., Hobbs, P.J., Meyer, R. and Davies, J. (2008) A Critical Overview of Transboundary Aquifers Shared by South Africa. Hydrogeology Journal, 16, 1207-1214. https://doi.org/10.1007/s10040-008-0285-2

[26] Mapeo, R.B.M. and Wingate, M.T.D. (2009) SHRIMP U-Pb Zircon Age for the Segwagwa-Masoke Igneous Complex of Southeastern Botswana and Implications for the Deformation History of the Achaean to Proterozoic Transvaal Supergroup of Southern Africa. Journal of African Earth Sciences, 54, 97-106.

[27] Stettler, E.H., de Beer, J.H., Eberle, D., Ludden, J. And Mareschal, M. (1997) Geophysics and Deep Structures. In: de Wit, M.J. and Ashwal, L.D., Eds., Greenstone Belts, Oxford Monograph on Geology and Geophysics, Clarendon Press, Oxford, 567-580.

[28] Poujol, M., Anhaeusser, C.R. and Armstrong, R.A. (2002) Episodic Granitoid Emplacement in the Archaean Amalia-Kraaipan Terrane, South Africa: Confirmation from Single Zircon U-Pb Geochronology. Journal of African Earth Sciences, 35, 147-161.

[29] DWA (1991) Botswana National Water Master Plan Study, Vol. 5 Hydrogeology, Ministry of Minerals, Energy and Water Resources (MMWER), Gaborone DWA, 2006. Botswana National Water Master Plan. Final Report Volume 5 Hydrogeology, by SMEC in Association with EHES, Department of Water Affairs, Gaborone.

[30] Von Hoyer, M. and Struckmeier, W. (1989) A New Groundwater Resources Map for the Republic of Botswana at the Scale of 1:1000000. Botswana Notes and Records, 20, 101-107.

[31] DWA (2015) Department of Water Affairs, Water Boreholes in Botswana, Gaborone.

[32] Bakundukize, C., Mtoni, Y., Martens, K., Van Camp, M. and Walraevens, K. (2016) Poor Understanding of the Hydrogeological Structure Is a Main Cause of Hand-Dug Wells Failure in Developing Countries: A Case Study of a Precambrian Basement Aquifer in Bugesera Region (Burundi). Journal of African Earth Sciences, 121, 180-199.

[33] Dietvorst, E.J.L., De Vries, J.J. and Gieske, A. (1991) Coincidence of Well Fields and Tectonic Basins in the Precambrian Shield Area of Southeast Botswana. Groundwater, 29, 869-877. https://doi.org/10.1111/j.1745-6584.1991.tb00574.x

[34] Terblanche, M. and Stroebel, L. (2013) Case Study: Groundwater Exploration in the 
Basement Granites of the Kraaipan Group using Aeromagnetic Surveys. Groundwater: A New Paradigm. 13 th Biennial Groundwater Division Conference \& Exhibition, Durban, 17-19 September 2013. http://gwd.org.za/sites/gwd.org.za/files/

[35] Gibson, R.I. and Millegan, P.S. (1998) Geologic Applications of Gravity and Magnetics: Case Histories. Geophysical Reference Series 8, 162, Society of Exploration Geophysicists, Tulsa. https://doi.org/10.1190/1.9781560801832

[36] Hinze, W.J., von Frese, R.R.B. and Saad, A.H. (2013) Gravity and Magnetic Exploration: Principles, Practices, and Applications. Cambridge University Press, $512 \mathrm{p}$. https://doi.org/10.1017/CBO9780511843129

[37] Blakely, R.J. (1995) Potential Theory in Gravity and Magnetic Applications. Cambridge University Press, Cambridge, $441 \mathrm{p}$. https://doi.org/10.1017/CBO9780511549816

[38] Bierlein, F.P., Murphy, F.C., Weinberg, R.F. and Lees, T. (2006) Distribution of Orogenic Gold Deposits in Relation to Fault Zones and Gravity Gradients: Targeting Tools Applied to the Eastern Goldfields, Yilgarn Craton, Western Australia. Mineralium Deposita, 41, 107-126. https://doi.org/10.1007/s00126-005-0044-4

[39] Witherly, K. (2015) Building Effective Mineral System Models; The Importance of Merging Geophysical Observation with Geological Inference. ASEG-PESA 2015, Perth.

[40] Betts, P.G., Williams, H., Stewart, J. and Ailleres, L. (2007) Kinematic Analysis of Aeromagnetic Data: Looking at Geophysical Data in a Structural Context. Gondwana Research, 11, 582-583.

[41] Clark, D.A. (1997) Magnetic Petrophysics and Magnetic Petrology; Aids to Geological Interpretation of Magnetic Surveys. AGSO Journal of Australian Geology and Geophysics, 17, 83-103.

[42] Jaques, A.L., Wellman, P., Whitaker, A. and Wyborn, D. (1997) High-Resolution Geophysics in Modern Geological Mapping. AGSO Journal of Australian Geology and Geophysics, 17, 159-173.

[43] Milligan, P.R. and Gunn, P.J. (1997) Enhancement and Presentation of Airborne Geophysical Data. AGSO Journal of Australian Geology and Geophysics, 17, 63-76.

[44] Reeves, C.V., Reford, S.W. and Milligan, P.R. (1997) Airborne Geophysics-Old Methods, New Images. In: Gubbins, A.G., Ed., Proceedings of Exploration: 4 th Decennial International Conference on Mineral Exploration, 13-30.

[45] Broome, H.J. (1990) Generation and Interpretation of Geophysical Images with Examples from the Rae Province, Northwestern Canada Shield. Geophysics, 55, 977-997. https://doi.org/10.1190/1.1442927

[46] Roest, W.R., Verhoef, V. and Pilkington, M. (1992) Magnetic Interpretation using the 3-D Analytic Signal. Geophysics, 57, 116-125. https://doi.org/10.1190/1.1443174

[47] MacLeod, I.N., Jones, K. and Dai, T.F. (1993) 3-D Analytic Signal in the Interpretation of Total Magnetic Field Data at Low Magnetic Latitudes. Exploration Geophysics, 24, 679-688. https://doi.org/10.1071/EG993679

[48] Reid, A.B., Allsop, J.M., Granser, H., Millet, A.J. and Somerton, I.W. (1990) Magnetic Interpretation in Three Dimensions using Euler Deconvolution. Geophysics, 55, 80-91. https://doi.org/10.1190/1.1442774

[49] Reid, A.B., Ebbing, J. and Webb, S.J. (2014) Avoidable Euler Errors-The Use and Abuse of Euler Deconvolution Applied to Potential Fields. Geophysical Prospecting, 62, 1162-1168. https://doi.org/10.1111/1365-2478.12119 
[50] Reid, A.B. and Thurston, J.B. (2014) The Structural Index in Gravity and Magnetic Interpretation: Errors, Uses, and Abuses. Geophysics, 79, J61-J66. https://doi.org/10.1190/geo2013-0235.1

[51] Spector, A. and Grant, F.S. (1970) Statistical Models for Interpreting Aeromagnetic Data. Geophysics, 35, 293-302. https://doi.org/10.1190/1.1440092

[52] Telford, W.M., Geldart, L.P. and Sheriff, R.E. (1990) Applied Geophysics. 2nd Edition, Cambridge University Press, Cambridge, 770. https://doi.org/10.1017/CBO9781139167932

[53] Mare, L.P. and Oosthuizen, B.C. (2000) South African Geophysical Atlas. Physical Properties of South African Rocks. Council for Geoscience, Vol. 4.

[54] Peschler, A.P., Benn, K. and Roest, W.R. (2004) Insights on Archean Continental Geodynamics from Gravity Modelling of Granite-Greenstone Terranes. Journal of Geodynamics, 38, 185-207.

[55] Gwavava, O. and Ranganai, R.T. (2009) The Geology and Structure of the Masvingo Greenstone Belt and Adjacent Granite Plutons from Geophysical Data, Zimbabwe Craton. South African Journal of Geology, 112, 119-132.

https://doi.org/10.2113/gssajg.112.3-4.277

[56] Levin, M., Gat, J.R. and Issar, A. (1980) Precipitation, Flood and Groundwaters of the Negev Highlands: An Isotopic Study of Desert Hydrology. In: Proceedings Advisory Group Meeting, Arid Zone Hydrology. Investigations with Isotope Techniques, International Atomic Energy Agency, IAEA-AG-158/1, 3-22, Vienna.

[57] Soupios, P.M., Kouli, M., Vallianatos, F., Vafidis, A. and Stavroulakis, G. (2007) Estimation of Aquifer Hydraulic Parameters from Surficial Geophysical Methods: A Case Study of Keritis Basin in Chania (Crete-Greece). Journal of Hydrology, 338, 122-131. 